\title{
Binding of Filamentous Actin to CaMKII as a Potential Mechanism for the Regulation of Bidirectional Synaptic Plasticity by $\beta$ CaMKII in Cerebellar Purkinje Cells
}

\author{
Thiago M. Pinto ${ }^{1,2,}$, Maria J. Schilstra ${ }^{2}$, Antonio C. Roque ${ }^{3}$, Volker Steuber ${ }^{2}$
}

1 Instituto Federal de Educação, Ciência e Tecnologia do Rio de Janeiro, Nilópolis, RJ, 26530-060, Brazil

2 Centre for Computer Science and Informatics Research, University of Hertfordshire, Hatfield, Herts, AL10 9AB, UK

3 Departamento de Física, FFCLRP, Universidade de São Paulo, Ribeirão Preto, SP, 14040-901, Brazil

* thiago.pinto@ifrj.edu.br

\begin{abstract}
Calcium-calmodulin dependent protein kinase II (CaMKII) regulates many forms of synaptic plasticity, but little is known about its functional role during plasticity induction in the cerebellum. Experiments have indicated that the $\beta$ isoform of CaMKII controls the bidirectional inversion of plasticity at parallel fibre (PF)-Purkinje cell (PC) synapses in cerebellar cortex. Because the cellular events that underlie these experimental findings are still poorly understood, we developed a simple computational model to investigate how $\beta$ CaMKII regulates the direction of plasticity in cerebellar PCs. We present the first model of AMPA receptor phosphorylation that simulates the induction of long-term depression (LTD) and potentiation (LTP) at the PF-PC synapse. Our simulation results suggest that the balance of CaMKII-mediated phosphorylation and protein phosphatase 2B (PP2B)-mediated dephosphorylation of AMPA receptors can determine whether LTD or LTP occurs in cerebellar PCs. The model replicates experimental observations that indicate that $\beta$ CaMKII controls the direction of plasticity at PF-PC synapses, and demonstrates that the binding of filamentous actin to CaMKII can enable the $\beta$ isoform of the kinase to regulate bidirectional plasticity at these synapses.
\end{abstract}

\section{Author Summary}

Many molecules and the complex interactions between them are involved in synaptic plasticity in the cerebellum. However, the exact relationship between cerebellar plasticity and the different signalling cascades remains unclear. Calcium-calmodulin dependent protein kinase II (CaMKII) is an important component of the signalling network that is responsible for plasticity in cerebellar Purkinje cells (PCs). The CaMKII holoenzyme contains different isoforms such as $\alpha$ CaMKII and $\beta$ CaMKII. Experiments with Camk2b knockout mice that lack the $\beta$ isoform of CaMKII demonstrated that $\beta$ CaMKII regulates the direction of plasticity at parallel fibre (PF)-PC synapses. Stimulation protocols that induce long-term depression in wild-type mice, which contain both $\alpha$ and $\beta$ CaMKII, lead to long-term potentiation in knockout mice without 
$\beta$ CaMKII, and vice versa. We developed a kinetic simulation of the phosphorylation and dephosphorylation of AMPA receptors by CaMKII and protein phosphatase 2B to investigate how $\beta$ CaMKII can control bidirectional synaptic plasticity in cerebellar PCs. Our simulation results demonstrate that the binding of filamentous actin to $\beta$ CaMKII can contribute to the regulation of bidirectional plasticity at PF-PC synapses. Our computational model of intracellular signalling significantly advances the understanding of the mechanisms of synaptic plasticity induction in the cerebellum.

\section{Introduction}

The structure and neural circuitry of the cerebellum are well understood. The precision of the cerebellar anatomy has instigated the development of many theories that attempt to unravel cerebellar function. However, although it is known that the cerebellum contributes to motor learning and cognition, there is still no general agreement about its exact functional role [1-4].

Synaptic plasticity is an activity-dependent change in the strength of synaptic connections between pre and postsynaptic neurons. In cerebellar cortex, modifications in the strength of synaptic connections between parallel fibres (PFs) and Purkinje cells (PCs) such as long-term depression (LTD) and long-term potentiation (LTP) are thought to contribute to cerebellar learning [5-7].

PF LTD (often called cerebellar LTD) is a process in which the strength of the PF-PC synapse is depressed by large increases in the postsynaptic calcium concentration in response to the coincident activation of $\mathrm{PF}$ and climbing fibre $(\mathrm{CF})$ input onto the PC [8-13]. In addition to undergoing LTD, PF synapses can also exhibit LTP. The strengthening of excitatory synapses between PFs and PCs by PF LTP is mediated by smaller calcium concentration increases that can result from the activation of PFs without any coincident CF input to the PC. LTP is necessary to balance LTD at cerebellar PF-PC synapses in order to prevent saturation and to allow reversal of motor learning [14]. A large number of experimental [10,15-21] and several computer simulation studies $[11,13,22-27]$ have explored the biochemical pathways involved in PF LTD, but less is known about the mechanisms underlying PF LTP.

Calcium-calmodulin dependent protein kinase II (CaMKII), which is one of the most abundant proteins in the brain, is a multifunctional enzyme that phosphorylates a wide range of substrates [28-31]. CaMKII is a critical mediator of the calcium signalling systems that underlie the induction of synaptic plasticity. Although significant progress has been made in understanding the role of CaMKII in synaptic plasticity in other brain areas, little is known about its functional role during plasticity induction in the cerebellum.

Two CaMKII isoforms, $\alpha$ CaMKII and $\beta$ CaMKII, have been shown to mediate synaptic plasticity in the cerebellum, and therefore to be essential for cerebellar learning and memory formation [29,31-33]. Although $\beta$ CaMKII is the predominant isoform of CaMKII in the cerebellum, the exact role of $\beta$ CaMKII in cerebellar learning has yet to be established.

Experiments with Camk2b knockout mice, which have been genetically modified to prevent the expression of the gene encoding the $\beta$ isoform of CaMKII, have addressed the role of $\beta$ CaMKII in plasticity in cerebellar PCs. These studies demonstrated that the $\beta$ CaMKII isoform regulates the direction of cerebellar plasticity at PF-PC synapses [33]. Stimulation protocols that induce LTD in wild-type mice result in LTP in knockout mice that lack $\beta$ CaMKII, and vice versa (Figure 1). However, the underlying mechanism that may explain these experimental findings is not clear. Van Woerden et al [33] suggested that a biochemical difference between the $\alpha$ CaMKII and $\beta$ CaMKII isoforms could underlie the switch of the direction of synaptic plasticity. The $\beta$ CaMKII, 
but not $\alpha$ CaMKII, isoforms can bind to F-actin [34], which could result in sequestering of the CaMKII complex to F-actin, making it unavailable for AMPA receptor phosphorylation.

Figure 1. Schematic representation of bidirectional plasticity at PF-PC synapses. The experimental results obtained by Van Woerden and collaborators [33] are schematically represented in this figure. The scheme illustrates how changes in the CaMKII-driven pathway could evoke different activity levels of calcium-dependent kinase (blue), resulting in the inversion of plasticity for wild-type and Camk2b knockout mice (solid and dashed lines, respectively). LTD is generated when the kinase activity (blue) surpasses the phosphatase activity (red), whereas the opposite case induces LTP.

Because experimental observations by themselves have not been able to explain how CaMKII mediates plasticity in PCs, a new dynamic model of cerebellar LTD and LTP that includes CaMKII has the potential to enhance our understanding of cerebellar plasticity. To investigate the proposed function of $\beta$ CaMKII in cerebellar plasticity, we developed a mathematical model of the biochemical pathways underlying the calcium-dependent phosphorylation and dephosphorylation of AMPA receptors at PF-PC synapses. Computer simulations of our model were used to explore how $\beta$ CaMKII can mediate the observed reversal of plasticity in cerebellar PCs. Our results indicate that the binding of F-actin to CaMKII can indeed enable the $\beta$ CaMKII isoform to control the direction of plasticity at PF-PC synapses, as proposed by Van Woerden et al [33]. Moreover, our model predicts that the sign inversion of synaptic plasticity is based on two additional mechanisms - a reduction of the overall level of CaMKII in the Camk2b knockout mice, and a resulting increase in phosphatase activity in these mice. We present the first data-driven model of intracellular signalling pathways in cerebellar PCs that includes CaMKII and that is able to replicate the induction of LTD and LTP at this important cerebellar synapse.

\section{Methods}

To understand the role of $\beta$ CaMKII in cerebellar LTD and LTP at PF-PC synapses, we developed a mathematical model of the phosphorylation and dephosphorylation of AMPA receptors by CaMKII and protein phosphatase 2B (PP2B). The simple model of AMPA receptor phosphorylation consists of six reactions: calcium-calmodulin $\left(\mathrm{Ca}_{4} \mathrm{CaM}\right)$-dependent activation of CaMKII, CaMKII binding to F-actin, binding of calcium to calmodulin (CaM) to form $\mathrm{Ca}_{4} \mathrm{CaM}$, PP2B activation by $\mathrm{Ca}_{4} \mathrm{CaM}$, and AMPA receptor phosphorylation and dephosphorylation by, respectively, CaMKII and PP2B (Figure 2).

To simulate the mechanism of CaMKII autophosphorylation, we adopt a simplified version of the commonly used model of CaMKII activation by $\mathrm{Ca}_{4} \mathrm{CaM}$ developed by Dupont and collaborators [35]. Because Van Woerden and collaborators suggested that the binding of F-actin to CaMKII could underlie the switch of direction of plasticity [33], we incorporated the binding of F-actin to CaMKII into this model to simulate the plasticity induction in wild-type mice, whereas the F-actin binding was omitted in the knockout mice that lack $\beta$ CaMKII.

In the simple model of $\mathrm{Ca}_{4} \mathrm{CaM}$-mediated CaMKII autophosphorylation considered here, all CaMKII subunits of the simulated Camk2b knockout mice are in one of four states. Following the terminology and notational convention used by Dupont et al [35], the four states are referred to as $\mathrm{W}_{\mathrm{i}}, \mathrm{W}_{\mathrm{b}}, \mathrm{W}_{\mathrm{p}}$, and $\mathrm{W}_{\mathrm{a}}$, where the subscripts $\mathrm{i}, \mathrm{b}, \mathrm{p}$, and a stand for inactive, bound, phosphorylated, and autonomous, respectively. $\mathrm{W}_{\mathrm{i}}$ and $\mathrm{W}_{\mathrm{b}}$ are unphosphorylated, and $\mathrm{W}_{\mathrm{p}}$ and $\mathrm{W}_{\mathrm{a}}$ are phosphorylated states, while subunits in 
Figure 2. Model of bidirectional plasticity at PF-PC synapses. A. CaMKII activation by $\mathrm{Ca}_{4} \mathrm{CaM}$, and its binding to $\mathrm{F}$-actin (Ac). CaMKII subunits for simulations of Camk2b knockout mice are in one of four states: $\mathrm{W}_{\mathrm{i}}, \mathrm{W}_{\mathrm{b}}, \mathrm{W}_{\mathrm{p}}$, and $\mathrm{W}_{\mathrm{a}}$, where the subscripts i, b, p, and a refer to the respective subunit states: inactive, bound to $\mathrm{Ca}_{4} \mathrm{CaM}$, phosphorylated and bound to $\mathrm{Ca}_{4} \mathrm{CaM}$, and autonomous: phosphorylated, but dissociated from $\mathrm{Ca}_{4} \mathrm{CaM}$. The kinase can also bind to $\mathrm{Ac}$ and be in the $\mathrm{W}_{\mathrm{i}} \mathrm{Ac}$, $\mathrm{W}_{\mathrm{b}} \mathrm{Ac}, \mathrm{W}_{\mathrm{p}} \mathrm{Ac}$, and $\mathrm{W}_{\mathrm{a}} \mathrm{Ac}$ subunit states, but only in simulations of wild-type mice. Here, we allow the CaMKII subunits in the $\mathrm{W}_{\mathrm{a}}$ form to switch to the $\mathrm{W}_{\mathrm{i}}$ state. CaMKII is therefore gradually inactivated after calcium stimulation stops. The kinetic constants of the reversible $\mathrm{Ca}_{4} \mathrm{CaM}$ binding reactions are $\mathrm{k}_{\mathrm{ib}}, \mathrm{k}_{\mathrm{bi}}, \mathrm{k}_{\mathrm{pa}}, \mathrm{k}_{\mathrm{ap}}, \mathrm{k}_{\mathrm{iacbac}}$, $\mathrm{k}_{\text {baciac }}, \mathrm{k}_{\text {pacaac }}$ and $\mathrm{k}_{\text {aacpac }}$, whereas $\mathrm{k}_{\mathrm{iiac}}, \mathrm{k}_{\mathrm{iaci}}, \mathrm{k}_{\mathrm{bbac}}, \mathrm{k}_{\mathrm{bacb}}, \mathrm{k}_{\mathrm{ppac}}, \mathrm{k}_{\mathrm{pacp}}, \mathrm{k}_{\mathrm{aaac}}$ and $\mathrm{k}_{\text {aaca }}$ denote the speed of the reversible Ac binding reactions. The rates of the irreversible phosphorylation of $\mathrm{W}_{\mathrm{b}}$ and $\mathrm{W}_{\mathrm{b}} \mathrm{Ac}$ are $\mathrm{V}_{\mathrm{a}}$ and $\mathrm{V}_{\mathrm{ac}}$, respectively. B. Binding of four calcium ions $\left(4 \mathrm{Ca}^{2+}\right.$ ) to CaM to form $\mathrm{Ca}_{4} \mathrm{CaM}$. $\mathrm{k}_{\text {on }}$ and $\mathrm{k}_{\text {off }}$ are the rate constants of the reversible $4 \mathrm{Ca}^{2+}$ binding reaction. C. PP2B activation by $\mathrm{Ca}_{4} \mathrm{CaM}$. $\mathrm{PP}_{2} \mathrm{~B}_{\mathrm{i}}$ and $\mathrm{PP} 2 \mathrm{~B}_{\mathrm{ac}}$ are the inactive and active forms of PP2B. The respective rate constants of PP2B activation and inactivation are $\mathrm{k}_{\text {ppia }}$ and $\mathrm{k}_{\mathrm{ppai}}$. D. AMPA receptor phosphorylation and dephosphorylation by active CaMKII

$\left(\mathrm{CaMKII}_{\mathrm{ac}}=\mathrm{W}_{\mathrm{b}}+\mathrm{W}_{\mathrm{p}}+\mathrm{W}_{\mathrm{a}}\right)$ and $\mathrm{PP} 2 \mathrm{~B}_{\mathrm{ac}}$.

the $\mathrm{W}_{\mathrm{b}}$ and $\mathrm{W}_{\mathrm{p}}$ states have $\mathrm{Ca}_{4} \mathrm{CaM}$ bound, and $\mathrm{W}_{\mathrm{i}}$ and $\mathrm{W}_{\mathrm{a}}$ have not. The CaMKII subunits of wild-type mice can also be in states bound to F-actin (Ac): $\mathrm{W}_{\mathrm{i}} \mathrm{Ac}, \mathrm{W}_{\mathrm{b}} \mathrm{Ac}$, $\mathrm{W}_{\mathrm{p}} \mathrm{Ac}$, and $\mathrm{W}_{\mathrm{a}} \mathrm{Ac}$.

The binding of four calcium ions to $\mathrm{CaM}$ to form $\mathrm{Ca}_{4} \mathrm{CaM}$ is included in the model. Furthermore, the $\mathrm{Ca}_{4} \mathrm{CaM}$ complex not only activates CaMKII, but is also responsible for the activation of PP2B. Because binding of $\beta$ CaMKII to F-actin is thought to result in sequestration of the kinase holoenzyme [36], $\mathrm{W}_{\mathrm{b}} \mathrm{Ac}, \mathrm{W}_{\mathrm{p}} \mathrm{Ac}$ and $\mathrm{W}_{\mathrm{a}} \mathrm{Ac}$ are unavailable for AMPA receptor phosphorylation. In the model presented here, phosphorylation of AMPA receptors is therefore mediated by the active CaMKII subunits that are not bound to F-actin $\left(\mathrm{CaMKII}_{\mathrm{ac}}=\mathrm{W}_{\mathrm{b}}+\mathrm{W}_{\mathrm{p}}+\mathrm{W}_{\mathrm{a}}\right)$. All of the active PP2B contributes to the receptor dephosphorylation.

Although the cerebellum contains four times as much $\beta$ CaMKII as $\alpha$ CaMKII [29], the actual $\alpha: \beta$ CaMKII ratio is $1: 1$ in PCs $[32,33]$. Therefore, the CaMKII concentration for Camk2b knockout mice is set to half of the kinase concentration for wild-type mice in our model. Moreover, in accordance with experimental observations by Brocke et al that suggest that CaMKII isoforms have different affinities for $\mathrm{Ca}_{4} \mathrm{CaM}$ [37], $\beta \mathrm{CaMKII}$ has a greater affinity for $\mathrm{Ca}_{4} \mathrm{CaM}$ than $\alpha \mathrm{CaMKII}$ in our computer simulations.

All biochemical reactions in our model are represented by coupled ordinary differential equations (ODEs). The full kinetic model with its associated ODEs and the parameter values adopted in all simulations are given in the Supporting Information. All of the following results were obtained by numerically integrating these equations in XPPAUT (X-Windows Phase Plane plus Auto), a numerical tool for simulating dynamical systems, using the CVODE method with relative and absolute error tolerances of $10^{-10}$.

\section{Results}

Using simulations of our mathematical model, we first investigated the dependence of kinase and phosphatase activities on the postsynaptic intracellular calcium concentration for wild-type mice and Camk2b knockout mice. We varied the amplitude of calcium pulses, which are used as input to our model, and calculated the average 
concentrations of all biochemical compounds during the simulated period for each level of calcium concentration. The goal of these simulations was to compare the predictions of our computational model with the proposed explanation of the experimental findings by Van Woerden and collaborators [33] that is illustrated in schematic form in Figure 1.

Figure $3 \mathrm{~A}$ shows the resulting average concentrations of $\mathrm{CaMKII}_{\mathrm{ac}}$ and $\mathrm{PP} 2 \mathrm{~B}_{\mathrm{ac}}$ for wild-type mice and $C a m k 2 b$ knockout mice as we increase the average concentration of calcium during stimulation period. To create similar conditions as in a typical cerebellar plasticity induction protocol, which was also used by Van Woerden and colleagues [33], the input to the model consisted of calcium pulses applied at a rate of $1 \mathrm{~Hz}$ for $300 \mathrm{~s}$. The figure compares the resulting kinase and phosphatase concentrations averaged over the $300 \mathrm{~s}$ of calcium application with concentrations averaged over a longer time period of $6000 \mathrm{~s}$ in order to explore the continued behaviour of the system after the offset of calcium application.

Figure 3. Bidirectional plasticity at PF-PC synapses: kinase and phosphatase activities at different calcium concentrations. The figure shows simulation results that support the suggested explanation of the experimental observations in [33] (Figure 1). Low calcium concentrations that induce LTP in wild-type mice (solid) lead to LTD in Camk2b knockout mice (dashed), and vice versa. In the model, the F-actin binding to CaMKII occurs in wild-type mice, whereas in knockout mice the lack of $\beta$ CaMKII prevents the binding of CaMKII to F-actin. A. Average concentrations of CaMKII $\mathrm{ac}_{\mathrm{ac}}$ (blue) and $\mathrm{PP}_{\mathrm{B}} \mathrm{B}_{\mathrm{ac}}$ (red) as a function of average concentrations of pulsed calcium at $1 \mathrm{~Hz}$ for $300 \mathrm{~s}$. B. Average concentrations of unphosphorylated and phosphorylated AMPA receptors (red and blue, respectively) in response to the same stimulation protocols. In the left panels, all simulations last $300 \mathrm{~s}$, that is, the panel shows average concentrations of CaMKII $\mathrm{ac}_{\mathrm{ac}}, \mathrm{PP}_{\mathrm{B}} \mathrm{\textrm {ac }}$ and AMPA receptors in the presence of calcium signals applied at $1 \mathrm{~Hz}$ for $300 \mathrm{~s}$. The right panels show the average concentrations of these compounds during simulations that last $6000 \mathrm{~s}$, that is, continue for $5700 \mathrm{~s}$ after the offset of the $300 \mathrm{~s}$ stimulation.

In both cases, when concentrations were measured during and after the calcium stimulus, our simulation results confirm the explanation of the CaMKII-dependent switch of bidirectional plasticity that was originally put forward by Van Woerden et al [33]. Low calcium concentrations, which would be expected to result from PF input alone, evoke larger average concentrations of $\mathrm{PP}^{2} \mathrm{~B}_{\mathrm{ac}}$ than $\mathrm{CaMKII}_{\mathrm{ac}}$ in simulated wild-type mice. In contrast, for Camk2b knockout mice, in which the lack of $\beta$ CaMKII prevents the binding of the CaMKII holoenzyme to F-actin, this relationship is reversed, with low calcium concentrations activating CaMKII more strongly than PP2B.

Furthermore, high calcium concentrations, in the range of those expected to be caused by coincident $\mathrm{PF}$ and $\mathrm{CF}$ input, lead to higher concentrations of $\mathrm{CaMKII}_{\mathrm{ac}}$ than $\mathrm{PP}_{2} \mathrm{~B}_{\mathrm{ac}}$ in wild-type mice, but larger phosphatase than kinase activities in Camk2b knockout mice (Figure 3A).

However, in spite of the similarity of our simulation results with the mechanism predicted by Van Woerden and collaborators [33], a comparison of Figures 1 and 3A also reveals a subtle difference. In the schematic originally proposed by Van Woerden et al (Figure 1), the CaMKII-dependent synaptic switch was assumed to be entirely mediated by a change in CaMKII activity due to the genetic Camk2b knockout, with low calcium concentrations resulting in increased CaMKII activity in knockout mice, while high calcium concentrations were proposed to lead to reduced CaMKII activity compared to wild-type mice. Our simulation results (Figure 3A) indicate that the proposed reduction in CaMKII activity for larger calcium concentrations is augmented by a coincident increase in PP2B activity. These results predict that an increase in the $\mathrm{PP}_{2} \mathrm{~B}_{\mathrm{ac}}$ concentration acts in tandem with a decrease in the CaMKII ${ }_{\mathrm{ac}}$ concentration to 
convert LTD to LTP for large calcium concentrations, or coincident PF and CF input, in the Camk2b knockout mice.

The effect of CaMKII and PP2B on cerebellar synaptic plasticity is mediated by the phosphorylation and dephosphorylation of AMPA receptors, respectively, with AMPA receptor phosphorylation leading to the internalization and removal of AMPA receptors from the postsynaptic membrane and the induction of LTD. Thus, we also investigated the effect of the simulated Camk2b knockout on AMPA receptor phosphorylation for different calcium concentrations. Figure 3B shows the resulting average concentrations of phosphorylated and unphosphorylated AMPA receptors as the amount of postsynaptic intracellular calcium increases for wild-type and Camk2b knockout mice. For simplicity and in the absence of any other knowledge, we assume that the initial concentrations of phosphorylated and unphosphorylated AMPA receptors at a calcium concentration of zero are equal, that is, half of the AMPA receptors are

unphosphorylated and the other half are phosphorylated. As in Figure 3A, we compare average concentrations of AMPA receptors during the $300 \mathrm{~s}$ calcium application protocol (Figure 3B, left panel) with those averaged over $6000 \mathrm{~s}$ (Figure 3B, right panel), lasting for $5700 \mathrm{~s}$ after the offset of the calcium stimulus. When measured during the $300 \mathrm{~s}$ period of calcium application, the concentration of unphosphorylated AMPA receptors in wild-type mice initially increases with an increased calcium concentration, peaks at an average calcium concentration of about $0.2 \mu \mathrm{M}$, and drops off below its initial value for higher calcium concentrations. As expected from the simulated activation of CaMKII and PP2B (Figure 3A), Camk2b knockout mice show the opposite behavior: the average concentration of unphosphorylated AMPA receptors during the stimulation period first decreases as the calcium concentration is raised, reaches a minimum where the unphosphorylated AMPA receptors in wild-type mice are at their maximum, and rises above its initial value for higher calcium concentrations. A similar behaviour is observed when the concentration of receptors is averaged over $6000 \mathrm{~s}$, but there is a noticeable difference at very low calcium concentrations (below $0.1 \mu \mathrm{M}$ ) where the levels of unphosphorylated and phosphorylated AMPA receptors are similar for both types of mice. For these very low calcium concentrations, CaMKII is only weakly activated and the concentration of $\mathrm{CaMKII}_{\mathrm{ac}}$ rapidly drops after the calcium stimulation stops. In this case, the CaMKII ${ }_{\mathrm{ac}}$ decay is much faster than the deactivation of PP2B, favouring the dephosphorylation of AMPA receptors (compare Figure $6 \mathrm{~A}$ for wild-type mice). In other respects, however, the results for $6000 \mathrm{~s}$ replicate those for $300 \mathrm{~s}$, with increased (decreased) concentrations of unphosphorylated AMPA receptors for wild-type (knockout) mice at low calcium concentrations at around $0.2 \mu \mathrm{M}$, and decreased (increased) levels of unphosphorylated AMPA receptors for wild-type (knockout) mice for higher calcium concentrations (above $0.3 \mu \mathrm{M}$ ). Given that the level of unphosphorylated (and not internalized) AMPA receptors determines the strength of the PF-PC synapses, our simulations therefore replicate the experimental results by Van Woerden et al [33]: in wild-type mice, LTP occurs at low calcium concentrations and LTD at high calcium concentrations, while knockout mice that lack $\beta$ CaMKII exhibit LTD at low calcium concentrations and LTP at high calcium concentrations.

To examine in more detail how the concentrations of the different biochemical species evolve over time, we analysed the temporal evolution of kinase and phosphatase activities and AMPA receptor concentrations during and after the application of $\mathrm{PF}$ input alone, and compared these with their temporal evolution in response to coincident $\mathrm{PF}$ and $\mathrm{CF}$ input. The temporal evolution of unphosphorylated and phosphorylated AMPA receptors in wild-type and knockout mice in response to the two stimulation protocols is shown in Figures 4A and 4B. In wild-type mice, the application of smaller calcium pulses that are triggered by $\mathrm{PF}$ input alone (Figure 4A, inset) results in concentrations of unphosphorylated AMPA receptors that start exceeding their initial 
value after about $100 \mathrm{~s}$ of PF stimulation, leading to LTP induction. In Camk2b knockout mice, PF input without CF input rapidly decreases the level of unphosphorylated AMPA receptors, indicating the induction of LTD rather than LTP (Figure 4A). In contrast, as shown in Figure 4B, in response to the larger calcium pulses that result from the coincident activation of $\mathrm{PF}$ and $\mathrm{CF}$ input (Figure $4 \mathrm{~B}$, inset), wild-type mice exhibit a decrease in unphosphorylated AMPA receptors and therefore LTD, while the Camk2b knockout leads to an increase in the concentration of unphosphorylated AMPA receptors, which corresponds to the induction of LTP.

Figure 4. Temporal evolution of AMPA receptor phosphorylation illustrates bidirectional plasticity at PF-PC synapses in response to $\mathbf{P F}$ and CF input. Bidirectional plasticity at this synapse is also observed when plotting the temporal evolution of unphosphorylated and phosphorylated AMPA receptors (red and blue, respectively) for wild-type and Camk2b knockout mice (solid and dashed, respectively) in response to low calcium concentration resulting from the $\mathrm{PF}$ input alone (A, pulse amplitude of $1.8 \mu \mathrm{M}$ ), and high calcium concentration as a result of the paired $\mathrm{PF}$ and $\mathrm{CF}$ stimulation (B, pulse amplitude of $10 \mu \mathrm{M})$.

In some cases, the temporal evolution of the AMPA receptor concentrations in the simulations is biphasic. For example, PF input alone in wild-type mice leads to an initial decrease in the level of unphosphorylated receptors that is followed by an increase above the initial baseline (Figure 4A, top panel). To understand the time course of the AMPA receptor phosphorylation and dephosphorylation, we analysed the temporal evolution of the activation of CaMKII and PP2B in the presence of synaptic input (Figure 5), and their deactivation when the synaptic input ceases (Figure 6). Figures 5A and $6 \mathrm{~A}$ indicate that the biphasic nature of the AMPA receptor phosphorylation and dephosphorylation is based on the different rates of CaMKII and PP2B activation in the model. For both wild-type and Camk2b knockout mice, the activation of CaMKII is faster than that of PP2B, which leads an initial increase of the number of phosphorylated (and a decrease in the number of unphosphorylated) AMPA receptors in all cases (Figure 4). However, in the presence of the F-actin binding of CaMKII in wild-type mice, the low calcium concentrations that result from PF input alone do not activate the kinase sufficiently, and the activation of PP2B surpasses the activation of CaMKII, which leads to the induction of LTP (Figures 5A and 6A, top panel). In contrast, LTD occurs for PF input alone in knockout mice, where more CaMKII is available for activation, so that the concentration of activated CaMKII exceeds that of PP2B (Figures 5A and 6A, bottom panel).

Figure 5. Temporal evolution of active CaMKII and PP2B during the application of PF and CF input. Evolution of concentrations of $\mathrm{CaMKII}_{\mathrm{ac}}$ (blue) and PP2B $\mathrm{B}_{\mathrm{ac}}$ (red) in wild-type mice (top, solid) and Camk2b knockout mice (bottom, dashed) in response to low calcium concentrations as a result of the PF input alone ( $\mathbf{A}$, pulse amplitude of $1.8 \mu \mathrm{M})$, and high calcium concentrations resulting from coincident $\mathrm{PF}$ and $\mathrm{CF}$ stimulation (B, pulse amplitude of $10 \mu \mathrm{M})$. In this figure, simulations last $300 \mathrm{~s}$ which is the duration of calcium stimulation.

Figures $5 \mathrm{~B}$ and $6 \mathrm{~B}$ show that the opposite scenario occurs for coincident $\mathrm{PF}$ and $\mathrm{CF}$ input. The higher levels of calcium that result from the paired $\mathrm{PF}$ and $\mathrm{CF}$ stimulation result in much stronger activation of CaMKII and PP2B. In wild-type mice, the CaMKII activation exceeds the activation of PP2B, leading to LTD (Figures 5B and 6B, top panel). However, the reduction of the overall CaMKII concentration because of the Camk2b knockout means that the level of $\mathrm{PP}_{2} \mathrm{~B}_{\mathrm{ac}}$ in the knockout mice is higher than that of $\mathrm{CaMKII}_{\mathrm{ac}}$ and LTP occurs (Figures $5 \mathrm{~B}$ and $6 \mathrm{~B}$, bottom panel). 
Figure 6. Continued temporal evolution of active CaMKII and PP2B after the application of synaptic input. Temporal evolution of $\mathrm{CaMKII}_{\mathrm{ac}}$ (blue) and $\mathrm{PP}_{2} \mathrm{~B}_{\mathrm{ac}}$ (red) in wild-type mice (top, solid) and Camk2b knockout mice (bottom, dashed) in response to low calcium concentrations as a result of the PF input alone (A, pulse amplitude of $1.8 \mu \mathrm{M}$ ), and high calcium concentrations resulting from coincident $\mathrm{PF}$ and $\mathrm{CF}$ stimulation $(\mathbf{B}$, pulse amplitude of $10 \mu \mathrm{M})$. Here, all simulations last $6000 \mathrm{~s}$ to investigate what occurs with $\mathrm{CaMKII}_{\mathrm{ac}}$ and $\mathrm{PP} 2 \mathrm{~B}_{\mathrm{ac}}$ concentrations after calcium input signals that last $300 \mathrm{~s}$.

\section{Discussion}

LTD of synapses between PFs and PCs in cerebellar cortex is thought to be the basis of cerebellar learning [5-7]. Postsynaptic LTD at PF-PC synapses is balanced by postsynaptic LTP, but the exact conditions and cellular mechanisms that determine the direction of synaptic plasticity induction in vivo are not fully understood. PF LTD and LTP are mediated by the phosphorylation and dephosphorylation of AMPA receptors $[11,38]$ and regulated by a kinase/phosphatase switch involving enzymes such as CaMKII [29,31-33] and PP2B [14]. The control of bidirectional plasticity by CaMKII has received particular attention, after experiments by Van Woerden and collaborators with Camk2b knockout mice [33] indicated that the beta isoform of CaMKII plays a central role in determining the direction of synaptic weight change. In Camk2b knockout mice that lack $\beta$ CaMKII, stimulation protocols that normally lead to the induction of LTD resulted in LTP, and vice versa [33]. Van Woerden et al [33] suggested that this reversal of synaptic plasticity in the Camk2b knockout mice could be based on binding of $\beta$ CaMKII to F-actin in wild-type mice, which might reduce the concentration of CaMKII that is available for the phosphorylation of AMPA receptors under these normal conditions.

To test this hypothesis and investigate whether (and under which conditions) F-actin binding of CaMKII in wild-type mice, and the lack of F-actin binding in Camk2b knockout mice, can indeed lead to the observed reversal of synaptic plasticity at PF-PC synapses, we developed a simple mathematical model of AMPA receptor phosphorylation and dephosphorylation by CaMKII and PP2B. In our model, F-actin binding to CaMKII was included in wild-type mice that contain both $\alpha$ and $\beta$ kinase isoforms. In contrast, in simulations of Camk2b knockout mice that lack $\beta$ CaMKII the F-actin binding was omitted, and the total concentration of CaMKII was reduced to half of the value for wild-type mice. Simulation results of the model support the suggestion by Van Woerden and colleagues [33]. Moreover, they go beyond their original suggestion [33] and predict that the sign reversal of synaptic plasticity is based on a combination of three mechanisms operating at different postsynaptic calcium concentrations. At low calcium concentrations such as those that result from PF input alone, and that evoke LTP in wildtype mice, the lack of F-actin binding of CaMKII in Camk2b knockout mice leads to a level of active and available CaMKII that exceeds the level of active PP2B; this results in induction of LTD in these mutant mice. For the high calcium concentrations that occur in response to a classic LTD induction protocol, that is, coincident $\mathrm{PF}$ and $\mathrm{CF}$ input in wildtype mice, two mechanisms operate together. The loss of $\beta$ CaMKII in the knockout mice causes a reduction in the total concentration of CaMKII. As a consequence, less CaMKII is available for the phosphorylation of AMPA receptors, and more $\mathrm{Ca}_{4} \mathrm{CaM}$ is left available for the activation of PP2B. Thus, the model predicts that the combination of a decreased kinase activity and an increased phosphatase activity is responsible for the switch from LTD to LTP for high calcium concentrations in Camk2b knockout mice.

Although there are many computational models that investigate the biochemical 
processes underlying LTD at PF-PC synapses [11,13,22-27], none of these models has been set up to model the induction of LTP at these synapses. Moreover, despite experimental evidence for the involvement of CaMKII in PF LTD and LTP [29,31-33], the CaMKII pathway has, so far, not been included in the signalling cascades of existing PF-PC synaptic plasticity models. The present simple model is the first model of intracellular signalling at PF-PC synapses that focusses on the role of CaMKII and that models the induction of both LTD and LTP in wildtype and Camk2b knockout mice. In order to concentrate on the role of $\beta$ CaMKII in bidirectional synaptic plasticity, the model has been kept intentionally simple. In future work, however, the biological realism of the model could be incrementally extended by adding components of existing models of PF LTD. A comparison of results obtained from our simple model with a more complex one could then be used to identify the potential contribution of other biochemical species to regulating the sign reversal of synaptic plasticity in cerebellar PCs.

Most modelling studies of intracellular signalling are based on the assumption that ionic and molecular concentrations can be described by mass action kinetics, and it is often assumed that reactions between chemical species occur in a single well-stirred compartment. As in the present model, this assumption leads to deterministic solutions of systems of ordinary differential equations. However, many signalling cascades involve very small numbers of molecules or ions, which are more faithfully represented by stochastic models [39-41]. As a complement to our deterministic model of intracellular signalling at the PF-PC synapse, a stochastic model of bidirectional plasticity at this synapse, which also accounts for spatial aspects of cellular signalling, should be developed. Results obtained from both deterministic and stochastic computational models should then be compared.

Previous models of cerebellar LTD have measured synaptic plasticity by quantifying the concentrations or densities of phosphorylated and unphosphorylated AMPA receptors [11,24]. Indeed, this is the case for the simple model proposed here. However, Antunes and De Schutter have recently suggested that the extent of synaptic plasticity should be measured as a reduction in the number of synaptic AMPA receptors, rather than the concentration of phosphorylated receptors [42]. A next step in this research could be the inclusion of the AMPA receptor trafficking modelled by Antunes and De Schutter into the model of bidirectional plasticity at PF-PC synapses. Moreover, several concentrations of biochemical compounds and kinetic rate constants are free parameters, due to the lack of experimental data. Additional experiments will lead to an incremental improvement of the computational model, which in turn might suggest new experiments that need to be conducted.

\section{Supporting Information}

\section{Bidirectional Synaptic Plasticity Model}

To study the role of calcium-calmodulin dependent protein kinase II (CaMKII) in cerebellar plasticity, we first propose a rationalized version of the simple model of CaMKII activation developed by Dupont and collaborators [35]. In the model for CaMKII activation by calcium-calmodulin $\left(\mathrm{Ca}_{4} \mathrm{CaM}\right)$ considered here, CaMKII subunits for Camk2b knockout mice can be in four different states: inactive $\left(\mathrm{W}_{\mathrm{i}}\right)$, bound to $\mathrm{Ca}_{4} \mathrm{CaM}\left(\mathrm{W}_{\mathrm{b}}\right)$, phosphorylated and bound to $\mathrm{Ca}_{4} \mathrm{CaM}\left(\mathrm{W}_{\mathrm{p}}\right)$, and autonomous $\left(\mathrm{W}_{\mathrm{a}}\right)$ : phosphorylated, but dissociated from $\mathrm{Ca}_{4} \mathrm{CaM}$. For wild-type mice that contain the $\alpha$ CaMKII and $\beta$ CaMKII isoforms, the kinase subunits can also be in states bound to filamentous actin (Ac): $\mathrm{W}_{\mathrm{i}} \mathrm{Ac}, \mathrm{W}_{\mathrm{b}} \mathrm{Ac}, \mathrm{W}_{\mathrm{p}} \mathrm{Ac}$, and $\mathrm{W}_{\mathrm{a}} \mathrm{Ac}$.

The CaMKII activation model developed by Dupont et al [35] was adapted here to 
include the CaMKII subunit states bound to Ac, and also to express all kinase states in concentrations rather than fractions. Therefore, the $\mathrm{W}_{\mathrm{i}}$ concentration may be computed from the mass conservation relation

$$
\left[\mathrm{W}_{\mathrm{i}}\right]=\left[\mathrm{W}_{\text {tot }}\right]-\left[\mathrm{W}_{\mathrm{b}}\right]-\left[\mathrm{W}_{\mathrm{p}}\right]-\left[\mathrm{W}_{\mathrm{a}}\right]-\left[\mathrm{W}_{\mathrm{i}} \mathrm{Ac}\right]-\left[\mathrm{W}_{\mathrm{b}} \mathrm{Ac}\right]-\left[\mathrm{W}_{\mathrm{p}} \mathrm{Ac}\right]-\left[\mathrm{W}_{\mathrm{a}} \mathrm{Ac}\right]
$$

where $[x]$ denotes the concentration of substance $x$, e.g. $\left[\mathrm{W}_{\text {tot }}\right]$ is the total concentration of CaMKII.

Subunits in the $\mathrm{W}_{\mathrm{b}}, \mathrm{W}_{\mathrm{p}}$, and $\mathrm{W}_{\mathrm{a}}$ states exhibit kinase activity, and can, therefore, phosphorylate CaMKII's targets, including adjacent subunits in the CaMKII multimer. To be "ready" for phosphorylation, such adjacent subunits must be in the $\mathrm{W}_{\mathrm{b}}$ state themselves. The overall phosphorylation rate associated with this process is indicated by $\mathrm{V}_{\mathrm{a}}$, which is calculated using a phenomenological non-linear function of kinase subunits in the $\mathrm{W}_{\mathrm{b}}, \mathrm{W}_{\mathrm{p}}$ and $\mathrm{W}_{\mathrm{a}}$ forms as in [35]

$$
\mathrm{V}_{\mathrm{a}}=\frac{\mathrm{K}_{\mathrm{a}}\left(\left(\mathrm{c}_{\mathrm{b}}\left[\mathrm{W}_{\mathrm{b}}\right]\right)^{2}+\left(\mathrm{c}_{\mathrm{b}}\left[\mathrm{W}_{\mathrm{b}}\right]\right)\left(\mathrm{c}_{\mathrm{p}}\left[\mathrm{W}_{\mathrm{p}}\right]\right)+\left(\mathrm{c}_{\mathrm{b}}\left[\mathrm{W}_{\mathrm{b}}\right]\right)\left(\mathrm{c}_{\mathrm{a}}\left[\mathrm{W}_{\mathrm{a}}\right]\right)\right)}{\left[\mathrm{W}_{\mathrm{tot}}\right]^{2}}
$$

where $c_{b}, c_{p}$ and $c_{a}$ are weighting factors proportional to the kinase activity of each active state.

The earlier model [35] includes an empirical cubic function $\left(\mathrm{K}_{\mathrm{a}}\right)$ to model the neighbouring autophosphorylation, allowing the mathematical model to reproduce the experimental results in [43]. The equation for $\mathrm{K}_{\mathrm{a}}$ is

$$
\mathrm{K}_{\mathrm{a}}=\mathrm{K}_{\mathrm{a}}^{\prime}\left(\mathrm{aT} \mathrm{a}+\mathrm{bT}_{\mathrm{a}}^{2}+\mathrm{cT}_{\mathrm{a}}^{3}\right)
$$

where the phenomenological rate for CaMKII autophosphorylation is $\mathrm{K}_{\mathrm{a}}^{\prime}$, a, b and c are parameters that Dupont et al adjusted to fit the experimental plots in [43], and $\mathrm{T}_{\mathrm{a}}$ is the total fraction of active subunits represented as

$$
\mathrm{T}_{\mathrm{a}}=\frac{\left[\mathrm{W}_{\mathrm{b}}\right]+\left[\mathrm{W}_{\mathrm{p}}\right]+\left[\mathrm{W}_{\mathrm{a}}\right]}{\left[\mathrm{W}_{\text {tot }}\right]}
$$

Once $\mathrm{Ca}_{4} \mathrm{CaM}$ binds to $\mathrm{W}_{\mathrm{i}}$, the resulting $\mathrm{W}_{\mathrm{b}}$ form can either be phosphorylated, release $\mathrm{Ca}_{4} \mathrm{CaM}$, or bind to $\mathrm{Ac}$. $\mathrm{W}_{\mathrm{b}}$ is an active CaMKII subunit that can also phosphorylate AMPA receptors (AMPARs). The equation for $\mathrm{W}_{\mathrm{b}}$ is therefore

$$
\begin{aligned}
\frac{d\left[\mathrm{~W}_{\mathrm{b}}\right]}{d t}= & -\mathrm{V}_{\mathrm{a}}\left[\mathrm{W}_{\mathrm{tot}}\right]+\mathrm{k}_{\mathrm{ib}}\left[\mathrm{W}_{\mathrm{i}}\right]\left[\mathrm{Ca}_{4} \mathrm{CaM}\right]-\mathrm{k}_{\mathrm{bi}}\left[\mathrm{W}_{\mathrm{b}}\right]- \\
& \mathrm{k}_{\mathrm{bbac}}\left[\mathrm{W}_{\mathrm{b}}\right][\mathrm{Ac}]+\mathrm{k}_{\mathrm{bacb}}\left[\mathrm{W}_{\mathrm{b}} \mathrm{Ac}\right]- \\
& \mathrm{k}_{\mathrm{f}_{\text {phos }}}\left[\mathrm{W}_{\mathrm{b}}\right][\mathrm{AMPAR}]+\left(\mathrm{k}_{\mathrm{b}_{\text {phos }}}+\mathrm{k}_{\text {cat }} \text { phos }_{\text {pho }}\right)\left[\mathrm{W}_{\mathrm{b}} \mathrm{AMPAR}\right],
\end{aligned}
$$

where $\left[\mathrm{Ca}_{4} \mathrm{CaM}\right]$ denotes the concentration of $\mathrm{Ca}_{4} \mathrm{CaM}$ and $\left[\mathrm{W}_{\mathrm{b}} \mathrm{AMPAR}\right]$ is the concentration of $\mathrm{W}_{\mathrm{b}}$ bound to AMPARs.

The $\mathrm{W}_{\mathrm{p}}$ subunit can release $\mathrm{Ca}_{4} \mathrm{CaM}$, switching to the $\mathrm{W}_{\mathrm{a}}$ state, or bind to $\mathrm{Ac}$ and form $\mathrm{W}_{\mathrm{p}}$ Ac. As for $\mathrm{W}_{\mathrm{b}}, \mathrm{W}_{\mathrm{p}}$ also phosphorylates AMPARs. The amount of $\mathrm{W}_{\mathrm{p}}$ is calculated as

$$
\begin{aligned}
\frac{d\left[\mathrm{~W}_{\mathrm{p}}\right]}{d t}= & \mathrm{V}_{\mathrm{a}}\left[\mathrm{W}_{\mathrm{tot}}\right]-\mathrm{k}_{\mathrm{pa}}\left[\mathrm{W}_{\mathrm{p}}\right]+\mathrm{k}_{\mathrm{ap}}\left[\mathrm{W}_{\mathrm{a}}\right]\left[\mathrm{Ca}_{4} \mathrm{CaM}\right]- \\
& \mathrm{k}_{\mathrm{ppac}}\left[\mathrm{W}_{\mathrm{p}}\right][\mathrm{Ac}]+\mathrm{k}_{\mathrm{pacp}}\left[\mathrm{W}_{\mathrm{p}} \mathrm{Ac}\right]- \\
& \mathrm{k}_{\mathrm{f}_{\mathrm{phos}}}\left[\mathrm{W}_{\mathrm{p}}\right][\mathrm{AMPAR}]+\left(\mathrm{k}_{\mathrm{b}_{\text {phos }}}+\mathrm{k}_{\mathrm{cat}_{\text {phos }}}\right)\left[\mathrm{W}_{\mathrm{p}} \mathrm{AMPAR}\right],
\end{aligned}
$$

where $\left[\mathrm{W}_{\mathrm{p}} \mathrm{AMPAR}\right]$ is the concentration of the complex of $\mathrm{W}_{\mathrm{p}}$ bound to AMPARs. 
$\mathrm{W}_{\mathrm{a}}$ can bind to either $\mathrm{Ca}_{4} \mathrm{CaM}$ or Ac, and phosphorylate AMPARs as well. In our model, we also allow the CaMKII subunits in the $\mathrm{W}_{\mathrm{a}}$ form to switch to the $\mathrm{W}_{\mathrm{i}}$ state. CaMKII is therefore gradually inactivated after calcium stimulation stops. Thus,

$$
\begin{aligned}
\frac{d\left[\mathrm{~W}_{\mathrm{a}}\right]}{d t}= & \mathrm{k}_{\mathrm{pa}}\left[\mathrm{W}_{\mathrm{p}}\right]-\mathrm{k}_{\mathrm{ap}}\left[\mathrm{W}_{\mathrm{a}}\right]\left[\mathrm{Ca}_{4} \mathrm{CaM}\right]- \\
& \mathrm{k}_{\mathrm{aaac}}\left[\mathrm{W}_{\mathrm{a}}\right][\mathrm{Ac}]+\mathrm{k}_{\mathrm{aaca}}\left[\mathrm{W}_{\mathrm{a}} \mathrm{Ac}\right]- \\
& \mathrm{k}_{\mathrm{f}_{\mathrm{phos}}}\left[\mathrm{W}_{\mathrm{a}}\right][\mathrm{AMPAR}]+\left(\mathrm{k}_{\mathrm{b}_{\mathrm{phos}}}+\mathrm{k}_{\mathrm{cat}_{\text {phos }}}\right)\left[\mathrm{W}_{\mathrm{a}} \mathrm{AMPAR}\right]- \\
& \mathrm{k}_{\mathrm{dephos}}\left[\mathrm{W}_{\mathrm{a}}\right],
\end{aligned}
$$

and $\left[\mathrm{W}_{\mathrm{a}} \mathrm{AMPAR}\right]$ is the amount of $\mathrm{W}_{\mathrm{a}}$ trapped to AMPARs.

Unlike the model in [35], the model used here does not include a separate "trapped" state in which apo-CaM (CaM without any calcium ions bound) is bound to CaMKII, mainly because dissociation of calcium and CaM cannot be distinguished experimentally (nor described thermodynamically) as two distinct processes. As a result, the values for the rate constants between the "trapped" CaM $\left(\mathrm{W}_{\mathrm{t}}\right)$ and $\mathrm{W}_{\mathrm{a}}$ states in [35] were adopted here as $\mathrm{k}_{\mathrm{ap}}$ and $\mathrm{k}_{\mathrm{pa}}$.

$\mathrm{W}_{\mathrm{i}} \mathrm{Ac}$ binds to $\mathrm{Ca}_{4} \mathrm{CaM}$ and changes to the active $\mathrm{W}_{\mathrm{b}} \mathrm{Ac}$ form, or dissociates from Ac and switches to the $\mathrm{W}_{\mathrm{i}}$ state. Changes in $\mathrm{W}_{\mathrm{i}} \mathrm{Ac}$ concentration are

$$
\begin{aligned}
\frac{d\left[\mathrm{~W}_{\mathrm{i}} \mathrm{Ac}\right]}{d t}= & \mathrm{k}_{\mathrm{iiac}}\left[\mathrm{W}_{\mathrm{i}}\right][\mathrm{Ac}]-\mathrm{k}_{\mathrm{iaci}}\left[\mathrm{W}_{\mathrm{i}} \mathrm{Ac}\right]- \\
& \mathrm{k}_{\text {iacbac }}\left[\mathrm{W}_{\mathrm{i}} \mathrm{Ac}\right]\left[\mathrm{Ca}_{4} \mathrm{CaM}\right]+\mathrm{k}_{\mathrm{baciac}}\left[\mathrm{W}_{\mathrm{b}} \mathrm{Ac}\right]
\end{aligned}
$$

$\mathrm{W}_{\mathrm{b}} \mathrm{Ac}$ can be phosphorylated by neighbouring active Ac-bound subunits: $\mathrm{W}_{\mathrm{b}}$ Ac itself, $\mathrm{W}_{\mathrm{p}} \mathrm{Ac}$ or $\mathrm{W}_{\mathrm{a}} \mathrm{Ac}$. The autophosphorylation process for Ac-bound CaMKII is analogous to the mechanism of autophosphorylation of the kinase unbound to Ac (Equations 2, 3 and 4). The autophosphorylation rate for Ac-bound CaMKII subunits $\left(\mathrm{V}_{\mathrm{ac}}\right)$ is therefore

$$
\mathrm{V}_{\mathrm{ac}}=\frac{\mathrm{K}_{\mathrm{ac}}\left(\left(\mathrm{c}_{\mathrm{b}}\left[\mathrm{W}_{\mathrm{b}} \mathrm{Ac}\right]\right)^{2}+\left(\mathrm{c}_{\mathrm{b}}\left[\mathrm{W}_{\mathrm{b}} \mathrm{Ac}\right]\right)\left(\mathrm{c}_{\mathrm{p}}\left[\mathrm{W}_{\mathrm{p}} \mathrm{Ac}\right]\right)+\left(\mathrm{c}_{\mathrm{b}}\left[\mathrm{W}_{\mathrm{b}} \mathrm{Ac}\right]\right)\left(\mathrm{c}_{\mathrm{a}}\left[\mathrm{W}_{\mathrm{a}} \mathrm{Ac}\right]\right)\right)}{\left[\mathrm{W}_{\mathrm{tot}}\right]^{2}}
$$

where

and

$$
\mathrm{K}_{\mathrm{ac}}=\mathrm{K}_{\mathrm{a}}^{\prime}\left(\mathrm{aT} \mathrm{ac}+\mathrm{bT}_{\mathrm{ac}}^{2}+\mathrm{cT}_{\mathrm{ac}}^{3}\right),
$$

$$
\mathrm{T}_{\mathrm{ac}}=\frac{\left[\mathrm{W}_{\mathrm{b}} \mathrm{Ac}\right]+\left[\mathrm{W}_{\mathrm{p}} \mathrm{Ac}\right]+\left[\mathrm{W}_{\mathrm{a}} \mathrm{Ac}\right]}{\left[\mathrm{W}_{\text {tot }}\right]} .
$$

$\mathrm{W}_{\mathrm{b}} \mathrm{Ac}$ can also switch to $\mathrm{W}_{\mathrm{i}} \mathrm{Ac}$ once $\mathrm{Ca}_{4} \mathrm{CaM}$ dissociates from this kinase subunit, or dissociate from $\mathrm{Ac}$ and change to $\mathrm{W}_{\mathrm{b}}$. Thus,

$$
\begin{aligned}
\frac{d\left[\mathrm{~W}_{\mathrm{b}} \mathrm{Ac}\right]}{d t}= & -\mathrm{V}_{\mathrm{ac}}\left[\mathrm{W}_{\text {tot }}\right]+\mathrm{k}_{\mathrm{iacbac}}\left[\mathrm{W}_{\mathrm{i}} \mathrm{Ac}\right]\left[\mathrm{Ca}_{4} \mathrm{CaM}\right]-\mathrm{k}_{\mathrm{baciac}}\left[\mathrm{W}_{\mathrm{b}} \mathrm{Ac}\right]+ \\
& \mathrm{k}_{\mathrm{bbac}}\left[\mathrm{W}_{\mathrm{b}}\right][\mathrm{Ac}]-\mathrm{k}_{\mathrm{bacb}}\left[\mathrm{W}_{\mathrm{b}} \mathrm{Ac}\right] .
\end{aligned}
$$

The phosphorylated Ac- and $\mathrm{Ca}_{4} \mathrm{CaM}$-bound form of CaMKII can release $\mathrm{Ca}_{4} \mathrm{CaM}$ and switch to the $\mathrm{W}_{\mathrm{a}} \mathrm{Ac}$ form, or dissociate from $\mathrm{Ac}$ and swap to the $\mathrm{W}_{\mathrm{p}}$ state. The concentration of $\mathrm{W}_{\mathrm{p}} \mathrm{Ac}$ at each time step is expressed as

$$
\begin{aligned}
\frac{d\left[\mathrm{~W}_{\mathrm{p}} \mathrm{Ac}\right]}{d t}= & \mathrm{V}_{\mathrm{ac}}\left[\mathrm{W}_{\text {tot }}\right]-\mathrm{k}_{\text {pacaac }}\left[\mathrm{W}_{\mathrm{p}} \mathrm{Ac}\right]+\mathrm{k}_{\text {aacpac }}\left[\mathrm{W}_{\mathrm{a}} \mathrm{Ac}\right]\left[\mathrm{Ca}_{4} \mathrm{CaM}\right]+ \\
& \mathrm{k}_{\mathrm{ppac}}\left[\mathrm{W}_{\mathrm{p}}\right][\mathrm{Ac}]-\mathrm{k}_{\mathrm{pacp}}\left[\mathrm{W}_{\mathrm{p}} \mathrm{Ac}\right]
\end{aligned}
$$


whereas $\mathrm{W}_{\mathrm{a}} \mathrm{Ac}$ can bind to $\mathrm{Ca}_{4} \mathrm{CaM}$ and switch to $\mathrm{W}_{\mathrm{p}} \mathrm{Ac}$, or dissociate from $\mathrm{Ac}$ and turn into $\mathrm{W}_{\mathrm{a}}$. The equation for $\mathrm{W}_{\mathrm{a}} \mathrm{Ac}$ is

$$
\begin{aligned}
\frac{d\left[\mathrm{~W}_{\mathrm{a}} \mathrm{Ac}\right]}{d t}= & \mathrm{k}_{\text {pacaac }}\left[\mathrm{W}_{\mathrm{p}} \mathrm{Ac}\right]-\mathrm{k}_{\mathrm{aacpac}}\left[\mathrm{W}_{\mathrm{a}} \mathrm{Ac}\right]\left[\mathrm{Ca}_{4} \mathrm{CaM}\right]+ \\
& \mathrm{k}_{\text {aaac }}\left[\mathrm{W}_{\mathrm{a}}\right][\mathrm{Ac}]-\mathrm{k}_{\mathrm{aaca}}\left[\mathrm{W}_{\mathrm{a}} \mathrm{Ac}\right] .
\end{aligned}
$$

$\mathrm{Ca}_{4} \mathrm{CaM}$ not only activates CaMKII, but can also bind to the inactive form of PP2B $\left(\mathrm{PP} 2 \mathrm{~B}_{\mathrm{i}}\right)$. The phosphatase then gets activated and switches to the PP2B $\mathrm{B}_{\mathrm{ac}}$ form.

PP2 $\mathrm{B}_{\mathrm{ac}}$ mediates the dephosphorylation of AMPA receptors. The temporal evolution of $\mathrm{PP}_{2} \mathrm{~B}_{\mathrm{i}}$ concentration is

$$
\frac{d\left[\mathrm{PP} 2 \mathrm{~B}_{\mathrm{i}}\right]}{d t}=-\mathrm{k}_{\mathrm{ppia}}\left[\mathrm{PP} 2 \mathrm{~B}_{\mathrm{i}}\right]\left[\mathrm{Ca}_{4} \mathrm{CaM}\right]+\mathrm{k}_{\mathrm{ppai}}\left[\mathrm{PP} 2 \mathrm{~B}_{\mathrm{ac}}\right]
$$

whereas $\mathrm{PP} 2 \mathrm{~B}_{\mathrm{ac}}$ concentration changes are expressed as

$$
\begin{aligned}
\frac{d\left[\mathrm{PP} \mathrm{B}_{\mathrm{ac}}\right]}{d t}= & \mathrm{k}_{\mathrm{ppia}}\left[\mathrm{PP} 2 \mathrm{~B}_{\mathrm{i}}\right]\left[\mathrm{Ca}_{4} \mathrm{CaM}\right]-\mathrm{k}_{\mathrm{ppai}}\left[\mathrm{PP} 2 \mathrm{~B}_{\mathrm{ac}}\right]- \\
& \mathrm{k}_{\mathrm{f}_{\mathrm{dephos}}}\left[\mathrm{PP} 2 \mathrm{~B}_{\mathrm{ac}}\right][\mathrm{AMPARP}]+ \\
& \left(\mathrm{k}_{\mathrm{b}_{\text {dephos }}}+\mathrm{k}_{\mathrm{cat}_{\text {dephos }}}\right)\left[\mathrm{PP} 2 \mathrm{~B}_{\mathrm{ac}} \mathrm{AMPARP}\right],
\end{aligned}
$$

where [PP2 $\left.\mathrm{B}_{\mathrm{ac}} \mathrm{AMPARP}\right]$ expresses the concentration of $\mathrm{PP}^{2} \mathrm{~B}_{\mathrm{ac}}$ bound to phosphorylated AMPA receptors (AMPARPs).

The evolution of unphosphorylated AMPA receptors at each time step is

$$
\begin{aligned}
\frac{d[\text { AMPAR }]}{d t}= & -\mathrm{k}_{\mathrm{f}_{\text {phos }}}\left[\mathrm{W}_{\mathrm{b}}\right][\mathrm{AMPAR}]+\mathrm{k}_{\mathrm{b}_{\text {phos }}}\left[\mathrm{W}_{\mathrm{b}} \mathrm{AMPAR}\right]- \\
& \mathrm{k}_{\mathrm{f}_{\mathrm{phos}}}\left[\mathrm{W}_{\mathrm{p}}\right][\mathrm{AMPAR}]+\mathrm{k}_{\mathrm{b}_{\text {phos }}}\left[\mathrm{W}_{\mathrm{p}} \mathrm{AMPAR}\right]- \\
& \mathrm{k}_{\mathrm{f}_{\text {phos }}}\left[\mathrm{W}_{\mathrm{a}}\right][\mathrm{AMPAR}]+\mathrm{k}_{\mathrm{b}_{\mathrm{phos}}}\left[\mathrm{W}_{\mathrm{a}} \mathrm{AMPAR}\right]+ \\
& \mathrm{k}_{\text {cat }_{\text {dephos }}}\left[\mathrm{PP} 2 \mathrm{~B}_{\mathrm{ac}} \mathrm{AMPARP}\right],
\end{aligned}
$$

where

$$
\begin{aligned}
& \frac{d\left[\mathrm{~W}_{\mathrm{b}} \mathrm{AMPAR}\right]}{d t}=\mathrm{k}_{\mathrm{f}_{\mathrm{phos}}}\left[\mathrm{W}_{\mathrm{b}}\right][\mathrm{AMPAR}]-\left(\mathrm{k}_{\mathrm{b}_{\text {phos }}}+\mathrm{k}_{\mathrm{cat}} \mathrm{at}_{\mathrm{phos}}\right)\left[\mathrm{W}_{\mathrm{b}} \mathrm{AMPAR}\right] \\
& \frac{d\left[\mathrm{~W}_{\mathrm{p}} \mathrm{AMPAR}\right]}{d t}=\mathrm{k}_{\mathrm{f}_{\mathrm{phos}}}\left[\mathrm{W}_{\mathrm{p}}\right][\mathrm{AMPAR}]-\left(\mathrm{k}_{\mathrm{b}_{\text {phos }}}+\mathrm{k}_{\mathrm{cat}_{\mathrm{phos}}}\right)\left[\mathrm{W}_{\mathrm{p}} \mathrm{AMPAR}\right], \\
& \frac{d\left[\mathrm{~W}_{\mathrm{a}} \mathrm{AMPAR}\right]}{d t}=\mathrm{k}_{\mathrm{f}_{\mathrm{phos}}}\left[\mathrm{W}_{\mathrm{a}}\right][\mathrm{AMPAR}]-\left(\mathrm{k}_{\mathrm{b}_{\text {phos }}}+\mathrm{k}_{\mathrm{cat}} \mathrm{phos}_{\mathrm{phos}}\right)\left[\mathrm{W}_{\mathrm{a}} \mathrm{AMPAR}\right]
\end{aligned}
$$

and

$$
\begin{aligned}
\frac{d\left[\mathrm{PP} 2 \mathrm{~B}_{\mathrm{ac}} \mathrm{AMPARP}\right]}{d t}= & \mathrm{k}_{\mathrm{f}_{\mathrm{dephos}}}\left[\mathrm{PP} 2 \mathrm{~B}_{\mathrm{ac}}\right][\mathrm{AMPARP}]- \\
& \left(\mathrm{k}_{\mathrm{b}_{\text {dephos }}}+\mathrm{k}_{\mathrm{cat}_{\text {dephos }}}\right)\left[\mathrm{PP} 2 \mathrm{~B}_{\mathrm{ac}} \text { AMPARP }\right] .
\end{aligned}
$$

Moreover, the equation that represents the evolution of AMPARPs is

$$
\begin{aligned}
\frac{d[\text { AMPARP }]}{d t}= & \mathrm{k}_{\text {cat }_{\text {phos }}}\left[\mathrm{W}_{\mathrm{b}} \mathrm{AMPAR}\right]+\mathrm{k}_{\mathrm{cat}_{\mathrm{phos}}}\left[\mathrm{W}_{\mathrm{p}} \mathrm{AMPAR}\right]+ \\
& \mathrm{k}_{\text {cat }_{\text {phos }}}\left[\mathrm{W}_{\mathrm{a}} \mathrm{AMPAR}\right]-\mathrm{k}_{\mathrm{f}_{\text {dephos }}}\left[\mathrm{PP} 2 \mathrm{~B}_{\mathrm{ac}}\right][\mathrm{AMPARP}]+ \\
& \mathrm{k}_{\mathrm{b}_{\text {dephos }}}\left[\mathrm{PP} 2 \mathrm{~B}_{\mathrm{ac}} \mathrm{AMPARP}\right] .
\end{aligned}
$$

Standard protocols of long-term depression (LTD) and long-term potentiation (LTP) induction normally involve repetitive calcium stimuli (such as $1 \mathrm{~Hz}$ for $300 \mathrm{~s}$ ). To 
generate calcium pulses with concentrations that reflect experimental data [10], our simple model that simulates the bidirectional synaptic plasticity in Purkinje cells uses a calcium dynamics model

$$
\frac{d[\mathrm{Ca}]}{d t}=-4 \mathrm{k}_{\mathrm{on}}[\mathrm{Ca}]^{4}[\mathrm{CaM}]+4 \mathrm{k}_{\mathrm{off}}\left[\mathrm{Ca}_{4} \mathrm{CaM}\right]+\gamma(t)-\kappa\left([\mathrm{Ca}]-\left[\mathrm{Ca}_{\min }\right]\right),
$$

where $[\mathrm{Ca}]$ is the calcium concentration. The term $\gamma(t)-\kappa\left([\mathrm{Ca}]-\left[\mathrm{Ca}_{\min }\right]\right)$ describes the simple model of calcium dynamics we adopted, where $\gamma(t)$ denotes calcium concentration increases at each time step whose values originate from an input table, $\kappa$ is a term that reflects the calcium removal through diffusion, pumps, exchanges, and $\left[\mathrm{Ca}_{\min }\right]$ is the basal calcium concentration.

Input with high calcium influx rates $(\gamma(t))$ was used to stimulate the model to generate realistic amplitudes of calcium in response to parallel fibre $(\mathrm{PF})$ alone and $\mathrm{PF}$ + climbing fibre $(\mathrm{CF})$ stimulations (Figure 7).

The temporal evolution of $\mathrm{CaM}$ is written as

$$
\frac{d[\mathrm{CaM}]}{d t}=-\mathrm{k}_{\mathrm{on}}[\mathrm{Ca}]^{4}[\mathrm{CaM}]+\mathrm{k}_{\mathrm{off}}\left[\mathrm{Ca}_{4} \mathrm{CaM}\right] .
$$

$\mathrm{Ca}_{4} \mathrm{CaM}$ results from the binding of four calcium ions to CaM, and activates PP2B, $\mathrm{W}_{\mathrm{b}}, \mathrm{W}_{\mathrm{p}}, \mathrm{W}_{\mathrm{b}} \mathrm{Ac}$ and $\mathrm{W}_{\mathrm{p}} \mathrm{Ac}$. The equation that represents the evolution of $\mathrm{Ca}_{4} \mathrm{CaM}$ concentration is

$$
\begin{aligned}
\frac{d\left[\mathrm{Ca}_{4} \mathrm{CaM}\right]}{d t}= & \mathrm{k}_{\mathrm{on}}[\mathrm{Ca}]^{4}[\mathrm{CaM}]-\mathrm{k}_{\mathrm{off}}\left[\mathrm{Ca}_{4} \mathrm{CaM}\right]- \\
& \mathrm{k}_{\mathrm{ppia}}\left[\mathrm{PP} 2 \mathrm{~B}_{\mathrm{i}}\right]\left[\mathrm{Ca}_{4} \mathrm{CaM}\right]+\mathrm{k}_{\mathrm{ppai}}\left[\mathrm{PP} 2 \mathrm{~B}_{\mathrm{ac}}\right]- \\
& \mathrm{k}_{\mathrm{ib}}\left[\mathrm{W}_{\mathrm{i}}\right]\left[\mathrm{Ca}_{4} \mathrm{CaM}\right]+\mathrm{k}_{\mathrm{bi}}\left[\mathrm{W}_{\mathrm{b}}\right]+ \\
& \mathrm{k}_{\mathrm{pa}}\left[\mathrm{W}_{\mathrm{p}}\right]-\mathrm{k}_{\mathrm{ap}}\left[\mathrm{W}_{\mathrm{a}}\right]\left[\mathrm{Ca}_{4} \mathrm{CaM}\right]- \\
& \mathrm{k}_{\text {iacbac }}\left[\mathrm{W}_{\mathrm{i}} \mathrm{Ac}\right]\left[\mathrm{Ca}_{4} \mathrm{CaM}\right]+\mathrm{k}_{\text {baciac }}\left[\mathrm{W}_{\mathrm{b}} \mathrm{Ac}\right]+ \\
& \mathrm{k}_{\text {pacaac }}\left[\mathrm{W}_{\mathrm{p}} \mathrm{Ac}\right]-\mathrm{k}_{\text {aacpac }}\left[\mathrm{W}_{\mathrm{a}} \mathrm{Ac}\right]\left[\mathrm{Ca}_{4} \mathrm{CaM}\right] .
\end{aligned}
$$

Figure 7. Pulsed calcium stimulation for cerebellar PF-PC synapses.

Calcium influx rates (top, $\gamma(t)$ in Equation 23) are used as input to our bidirectional synaptic plasticity model to generate the desired output of calcium spikes (bottom, [Ca] in Equation 23). These match experimental data in [10,11] (dashed) which represent stimulations of PF alone (A, pulse amplitude of $1.8 \mu \mathrm{M})$ and paired $\mathrm{PF}$ and $\mathrm{CF}(\mathbf{B}$, pulse amplitude of $10 \mu \mathrm{M})$. Both calcium stimulations are applied at $1 \mathrm{~Hz}$ for $300 \mathrm{~s}$.

\section{Model Parameters}

\section{Acknowledgments}

We thank Chris De Zeeuw, Freek Hoebeek and Zhenyu Gao for helpful discussions and suggestions.

\section{References}

1. Glickstein M. Thinking about the cerebellum. Brain. 2006;129(2):288-290.

2. Glickstein M, Strata P, Voogd J. Cerebellum: history. Neuroscience. 2009;162(3):549-559. 
Table 1. Values of kinetic parameters for modelling bidirectional plasticity at PF-PC synapses.

\begin{tabular}{|c|c|c|c|}
\hline Parameter description & Symbol & Value & Reference \\
\hline CaMKII total concentration for wild-type mice & $\mathrm{W}_{\text {tot }}$ & $26 \mu \mathrm{M}$ & \\
\hline CaMKII total concentration for Camk2b knockout mice & $\mathrm{W}_{\text {tot }}$ & $13 \mu \mathrm{M}$ & {$[32,33]$} \\
\hline F-actin total concentration & Ac & $10 \mu \mathrm{M}$ & \\
\hline Unphosphorylated AMPA receptor initial concentration & AMPAR & $0.5 \mu \mathrm{M}$ & [11] \\
\hline Phosphorylated AMPA receptor initial concentration & AMPARP & $0.5 \mu \mathrm{M}$ & [11] \\
\hline Basal calcium concentration & $\mathrm{Ca}_{\min }$ & $0.045 \mu \mathrm{M}$ & {$[26,44,45]$} \\
\hline CaM initial concentration & $\mathrm{CaM}$ & $36 \mu \mathrm{M}$ & \\
\hline Inactive PP2B initial concentration & $\mathrm{PP} 2 \mathrm{~B}_{\mathrm{i}}$ & $26 \mu \mathrm{M}$ & \\
\hline Phenomenological rate of CaMKII autophosphorylation & $\mathrm{K}_{\mathrm{a}}^{\prime}$ & $0.29 \mathrm{~s}^{-1}$ & {$[35]$} \\
\hline Coefficient of CaMKII activity at $\mathrm{W}_{\mathrm{b}}$ subunit & $c_{b}$ & $75 \%$ & [35] \\
\hline Coefficient of CaMKII activity at $\mathrm{W}_{\mathrm{p}}$ subunit & $c_{p}$ & $100 \%$ & {$[35]$} \\
\hline Coefficient of CaMKII activity at $\mathrm{W}_{\mathrm{a}}$ subunit & $c_{a}$ & $80 \%$ & [35] \\
\hline Fitting parameter a & a & 0.500 & \\
\hline Fitting parameter b & $\mathrm{b}$ & 1.956 & \\
\hline Fitting parameter c & $\mathrm{c}$ & -1.800 & \\
\hline Parameter that reflects calcium removal & $\kappa$ & $4 \times 10^{3}$ & \\
\hline Rate of association of $\mathrm{Ca}_{4} \mathrm{CaM}$ to a $\mathrm{W}_{\mathrm{i}}$ subunit & $\mathrm{k}_{\mathrm{ib}}$ & $10 \mu \mathrm{M}^{-1} \mathrm{~s}^{-1}$ & [35] \\
\hline Rate of dissociation of $\mathrm{Ca}_{4} \mathrm{CaM}$ from a $\mathrm{W}_{\mathrm{b}}$ subunit & $\mathrm{k}_{\mathrm{bi}}$ & $0.2 \mathrm{~s}^{-1}$ & [37] \\
\hline Rate of association of $\mathrm{Ca}_{4} \mathrm{CaM}$ to a $\mathrm{W}_{\mathrm{a}}$ subunit & $\mathrm{k}_{\mathrm{ap}}$ & $10 \mu \mathrm{M}^{-1} \mathrm{~s}^{-1}$ & {$[35]$} \\
\hline Rate of dissociation of $\mathrm{Ca}_{4} \mathrm{CaM}$ from a $\mathrm{W}_{\mathrm{p}}$ subunit & $\mathrm{k}_{\mathrm{pa}}$ & $0.004 \mathrm{~s}^{-1}$ & [36] \\
\hline Rate of association of $\mathrm{Ca}_{4} \mathrm{CaM}$ to a $\mathrm{W}_{\mathrm{i}} \mathrm{Ac}$ subunit & $\mathrm{k}_{\text {iacbac }}$ & $10 \mu \mathrm{M}^{-1} \mathrm{~s}^{-1}$ & {$[35]$} \\
\hline Rate of dissociation of $\mathrm{Ca}_{4} \mathrm{CaM}$ from a $\mathrm{W}_{\mathrm{b}} \mathrm{Ac}$ subunit & $\mathrm{k}_{\text {baciac }}$ & $1 \mathrm{~s}^{-1}$ & \\
\hline Rate of association of $\mathrm{Ca}_{4} \mathrm{CaM}$ to a $\mathrm{W}_{\mathrm{a}} \mathrm{Ac}$ subunit & $k_{\text {aacpac }}$ & $10 \mu \mathrm{M}^{-1} \mathrm{~s}^{-1}$ & {$[35]$} \\
\hline Rate of dissociation of $\mathrm{Ca}_{4} \mathrm{CaM}$ from a $\mathrm{W}_{\mathrm{p}} \mathrm{Ac}$ subunit & $k_{\text {pacaac }}$ & $0.02 \mathrm{~s}^{-1}$ & {$[36]$} \\
\hline Rate of CaMKII degradation & $\mathrm{k}_{\text {dephos }}$ & $0.0005 \mathrm{~s}^{-1}$ & \\
\hline Rate of association of F-actin to a $\mathrm{W}_{\mathrm{i}}$ subunit & $\mathrm{k}_{\mathrm{iiac}}$ & $10 \mu \mathrm{M}^{-1} \mathrm{~s}^{-1}$ & \\
\hline Rate of dissociation of F-actin from a $\mathrm{W}_{\mathrm{i}} \mathrm{Ac}$ subunit & $\mathrm{k}_{\text {iaci }}$ & $30.1 \mathrm{~s}^{-1}$ & \\
\hline Rate of association of F-actin to a $\mathrm{W}_{\mathrm{b}}$ subunit & $\mathrm{k}_{\mathrm{bbac}}$ & $10 \mu \mathrm{M}^{-1} \mathrm{~s}^{-1}$ & \\
\hline Rate of dissociation of F-actin from a $\mathrm{W}_{\mathrm{b}} \mathrm{Ac}$ subunit & $\mathrm{k}_{\mathrm{bacb}}$ & $150.5 \mathrm{~s}^{-1}$ & \\
\hline Rate of association of $\mathrm{F}$-actin to a $\mathrm{W}_{\mathrm{p}}$ subunit & $\mathrm{k}_{\mathrm{ppac}}$ & $10 \mu \mathrm{M}^{-1} \mathrm{~s}^{-1}$ & \\
\hline Rate of dissociation of $\mathrm{F}$-actin from a $\mathrm{W}_{\mathrm{p}} \mathrm{Ac}$ subunit & $\mathrm{k}_{\mathrm{pacp}}$ & $1505 \mathrm{~s}^{-1}$ & \\
\hline Rate of association of F-actin to a $\mathrm{W}_{\mathrm{a}}$ subunit & $\mathrm{k}_{\text {aaac }}$ & $10 \mu \mathrm{M}^{-1} \mathrm{~s}^{-1}$ & \\
\hline Rate of dissociation of $\mathrm{F}$-actin from a $\mathrm{W}_{\mathrm{a}} \mathrm{Ac}$ subunit & $\mathrm{k}_{\text {aaca }}$ & $301 \mathrm{~s}^{-1}$ & \\
\hline Rate of association of $\mathrm{Ca}_{4} \mathrm{CaM}$ to $\mathrm{PP}_{2} \mathrm{~B}_{\mathrm{i}}$ & $\mathrm{k}_{\text {ppia }}$ & $0.15 \mu \mathrm{M}^{-1} \mathrm{~s}^{-1}$ & \\
\hline Rate of dissociation of $\mathrm{Ca}_{4} \mathrm{CaM}$ from $\mathrm{PP}_{2} \mathrm{~B}_{\mathrm{ac}}$ & $k_{\text {ppai }}$ & $0.00042 \mathrm{~s}^{-1}$ & \\
\hline Rate of association of calcium to CaM & $\mathrm{k}_{\mathrm{on}}$ & $2 \times 10^{3} \mu \mathrm{M}^{-4} \mathrm{~s}^{-1}$ & \\
\hline Rate of dissociation of calcium from $\mathrm{Ca}_{4} \mathrm{CaM}$ & $\mathrm{k}_{\mathrm{off}}$ & $2.3 \times 10^{6} \mathrm{~s}^{-1}$ & \\
\hline Rates of AMPA receptor phosphorylation by CaMKII & $\mathrm{k}_{\mathrm{f}_{\mathrm{phos}}}$ & $0.5 \mu \mathrm{M}^{-1} \mathrm{~s}^{-1}$ & \\
\hline \multirow{5}{*}{ Rates of AMPA receptor dephosphorylation by PP2B } & $\mathrm{k}_{\mathrm{b}_{\mathrm{phos}}}$ & $72.283 \mathrm{~s}^{-1}$ & [11] \\
\hline & $\mathrm{k}_{\text {cat }_{\text {phos }}}$ & $6 \mathrm{~s}^{-1}$ & {$[11]$} \\
\hline & $\mathrm{k}_{\mathrm{f}_{\mathrm{dephos}}}$ & $0.5 \mu \mathrm{M}^{-1} \mathrm{~s}^{-1}$ & \\
\hline & $\mathrm{k}_{\mathrm{b}_{\text {dephos }}}$ & $72.283 \mathrm{~s}^{-1}$ & {$[11]$} \\
\hline & $\mathrm{k}_{\mathrm{cat}_{\mathrm{dephos}}}$ & $6 \mathrm{~s}^{-1}$ & [11] \\
\hline
\end{tabular}


3. Beaton A, Mariën P. Language, cognition and the cerebellum: Grappling with an enigma. Cortex. 2010;46(7):811-820.

4. D'Angelo E, Casali S. Seeking a unified framework for cerebellar function and dysfunction: from circuit operations to cognition. Front Neural Circuits. 2012;6:116.

5. Llinás R, Lang E, Welsh J. The cerebellum, LTD, and memory: alternative views. Learn Mem. 1997;3:445-455.

6. Hansel C, Linden DJ, D'Angelo E. Beyond parallel fiber LTD: the diversity of synaptic and non-synaptic plasticity in the cerebellum. Nat Neurosci. 2001 May;4(5):467-475.

7. Ito M. Cerebellar circuitry as a neuronal machine. Prog Neurobiol. 2006; $78(3-5): 272-303$.

8. Ito M, Kano M. Long-lasting depression of parallel fiber-Purkinje cell transmission induced by conjunctive stimulation of parallel fibers and climbing fibers in the cerebellar cortex. Neurosci Lett. 1982;33(3):253-258.

9. Ito M. Long-term depression. Annu Rev Neurosci. 1989;12(1):85-102.

10. Wang S, Denk W, Häusser M. Coincidence detection in single dendritic spines mediated by calcium release. Nat Neurosci. 2000;12:1266-1273.

11. Kuroda S, Schweighofer N, Kawato M. Exploration of signal transduction pathways in cerebellar long-term depression by kinetic simulation. J Neurosci. 2001;21(15):5693-5702.

12. Ito M. The molecular organization of cerebellar long-term depression. Nat Rev Neurosci. 2002;3(11):896-902.

13. Doi T, Kuroda S, Michikawa T, Kawato M. Inositol 1,4,5-trisphosphate-dependent Ca2+ threshold dynamics detect spike timing in cerebellar Purkinje cells. J Neurosci. 2005;25(4):950-961.

14. Belmeguenai A, Hansel C. A role for protein phosphatases 1, 2A, and 2B in cerebellar long-term potentiation. J Neurosci. 2005;25(46):10768-10772.

15. Linden D, Connor J. Participation of postsynaptic PKC in cerebellar long-term depression in culture. Science. 1991;254(5038):1656-1659.

16. Lev-Ram V, Jiang T, Wood J, Lawrence D, Tsien R. Synergies and coincidence requirements between NO, cGMP, and $\mathrm{Ca} 2+$ in the induction of cerebellar long-term depression. Neuron. 1997;18(6):1025-1038.

17. Kawasaki H, Fujii H, Gotoh Y, Morooka T, Shimohama S, Nishida E, et al. Requirement for mitogen-activated protein kinase in cerebellar long term depression. J Biol Chem. 1999;274(19):13498-13502.

18. Ito M. Cerebellar long-term depression: characterization, signal transduction, and functional roles. Physiol Rev. 2001;81(3):1143-1195.

19. Chung H, Steinberg J, Huganir R, Linden D. Requirement of AMPA receptor GluR2 phosphorylation for cerebellar long-term depression. Science. 2003;300(5626):1751-1755. 
20. Feil R, Hartmann J, Luo C, Wolfsgruber W, Schilling K, Feil S, et al. Impairment of LTD and cerebellar learning by Purkinje cell-specific ablation of cGMP-dependent protein kinase I. J Cell Biol. 2003;163(2):295-302.

21. Launey T, Endo S, Sakai R, Harano J, Ito M. Protein phosphatase 2A inhibition induces cerebellar long-term depression and declustering of synaptic AMPA receptor. Proc Natl Acad Sci U S A. 2004;101(2):676-681.

22. Fiala J, Grossberg S, Bullock D. Metabotropic glutamate receptor activation in cerebellar Purkinje cells as substrate for adaptive timing of the classically conditioned eye-blink response. J Neurosci. 1996;16(11):3760-3774.

23. Kotaleski J, Lester D, Blackwell K. Subcellular interactions between parallel fibre and climbing fibre signals in Purkinje cells predict sensitivity of classical conditioning to interstimulus interval. Integr Physiol Behav Sci. $2002 ; 37(4): 265-292$.

24. Tanaka K, Khiroug L, Santamaria F, Doi T, Ogasawara H, Ellis-Davies G, et al. $\mathrm{Ca} 2+$ requirements for cerebellar long-term synaptic depression: role for a postsynaptic leaky integrator. Neuron. 2007;54(5):787-800.

25. Kitagawa Y, Hirano T, Kawaguchi S. Prediction and validation of a mechanism to control the threshold for inhibitory synaptic plasticity. Mol Syst Biol. 2009;5:280.

26. Antunes G, De Schutter E. A stochastic signaling network mediates the probabilistic induction of cerebellar long-term depression. J Neurosci. 2012;32(27):9288-9300.

27. Kawaguchi Sy, Hirano T. Gating of long-term depression by $\mathrm{Ca} 2+$ /calmodulin-dependent protein kinase II through enhanced cGMP signalling in cerebellar Purkinje cells. J Physiol. 2013;591(7):1707-1730.

28. Hanson P, Schulman H. Neuronal Ca2+/calmodulin-dependent protein kinases. Annu Rev Biochem. 1992;61(1):559-601.

29. Fink C, Meyer T. Molecular mechanisms of CaMKII activation in neuronal plasticity. Curr Opin Neurobiol. 2002;12(3):293-299.

30. Hudmon A, Schulman H. Structure-function of the multifunctional Ca2+/calmodulin-dependent protein kinase II. Biochem J. 2002;364(3):593-611.

31. Lisman J, Schulman H, Cline H. The molecular basis of CaMKII function in synaptic and behavioural memory. Nat Rev Neurosci. 2002;3:175-190.

32. Hansel C, de Jeu M, Belmeguenai A, Houtman S, Buitendijk G, Andreev D, et al. alphaCaMKII is essential for cerebellar LTD and motor learning. Neuron. 2006;51(6):835-843.

33. Van Woerden G, Hoebeek F, Gao Z, Nagaraja R, Hoogenraad C, Kushner S, et al. [beta] CaMKII controls the direction of plasticity at parallel fiber-Purkinje cell synapses. Nat Neurosci. 2009;12(7):823-825.

34. Shen K, Teruel M, Subramanian K, Meyer T. CaMKII[beta] functions as an F-actin targeting module that localizes CaMKII[alpha]/[beta] heterooligomers to dendritic spines. Neuron. 1998;21(3):593-606.

35. Dupont G, Houart G, De Koninck P. Sensitivity of CaM kinase II to the frequency of $\mathrm{Ca} 2+$ oscillations: a simple model. Cell Calcium.

2003;34(6):485-497. 
36. Meyer T, Hanson P, Stryer L, Schulman H. Calmodulin trapping by calcium-calmodulin-dependent protein kinase. Science. 1992;256:1199-1201.

37. Brocke L, Chiang L, Wagner P, Schulman H. Functional implications of the subunit composition of neuronal CaM kinase II. J Biol Chem. 1999;274(32):22713-22722.

38. Lee H, Barbarosie M, Kameyama K, Bear M, Huganir R. Regulation of distinct AMPA receptor phosphorylation sites during bidirectional synaptic plasticity. Nature. 2000;405(6789):955-959.

39. Bhalla U. Signaling in small subcellular volumes. I. Stochastic and diffusion effects on individual pathways. Biophys J. 2004;87(2):733-744.

40. Bhalla U. Signaling in small subcellular volumes. II. Stochastic and diffusion effects on synaptic network properties. Biophys J. 2004;87(2):745-753.

41. Rao C, Wolf D, Arkin A. Control, exploitation and tolerance of intracellular noise. Nature. 2002;420(6912):231-237.

42. Antunes G, De Schutter E. A stochastic signaling network mediates the probabilistic induction of cerebellar long-term depression. J Neurosci. 2012 Jul;32(27):9288-9300.

43. De Koninck P, Schulman H. Sensitivity of CaM kinase II to the frequency of Ca2+ oscillations. Science. 1998;279(5348):227-230.

44. Airaksinen M, Eilers J, Garaschuk O, Thoenen H, Konnerth A, Meyer M. Ataxia and altered dendritic calcium signaling in mice carrying a targeted null mutation of the calbindin D28k gene. Proc Natl Acad Sci USA. 1997;94(4):1488-1493.

45. Schmidt H, Stiefel K, Racay P, Schwaller B, Eilers J. Mutational analysis of dendritic $\mathrm{Ca} 2+$ kinetics in rodent Purkinje cells: role of parvalbumin and calbindin D28k. J Physiol. 2003;551(Pt 1):13-32. 
A

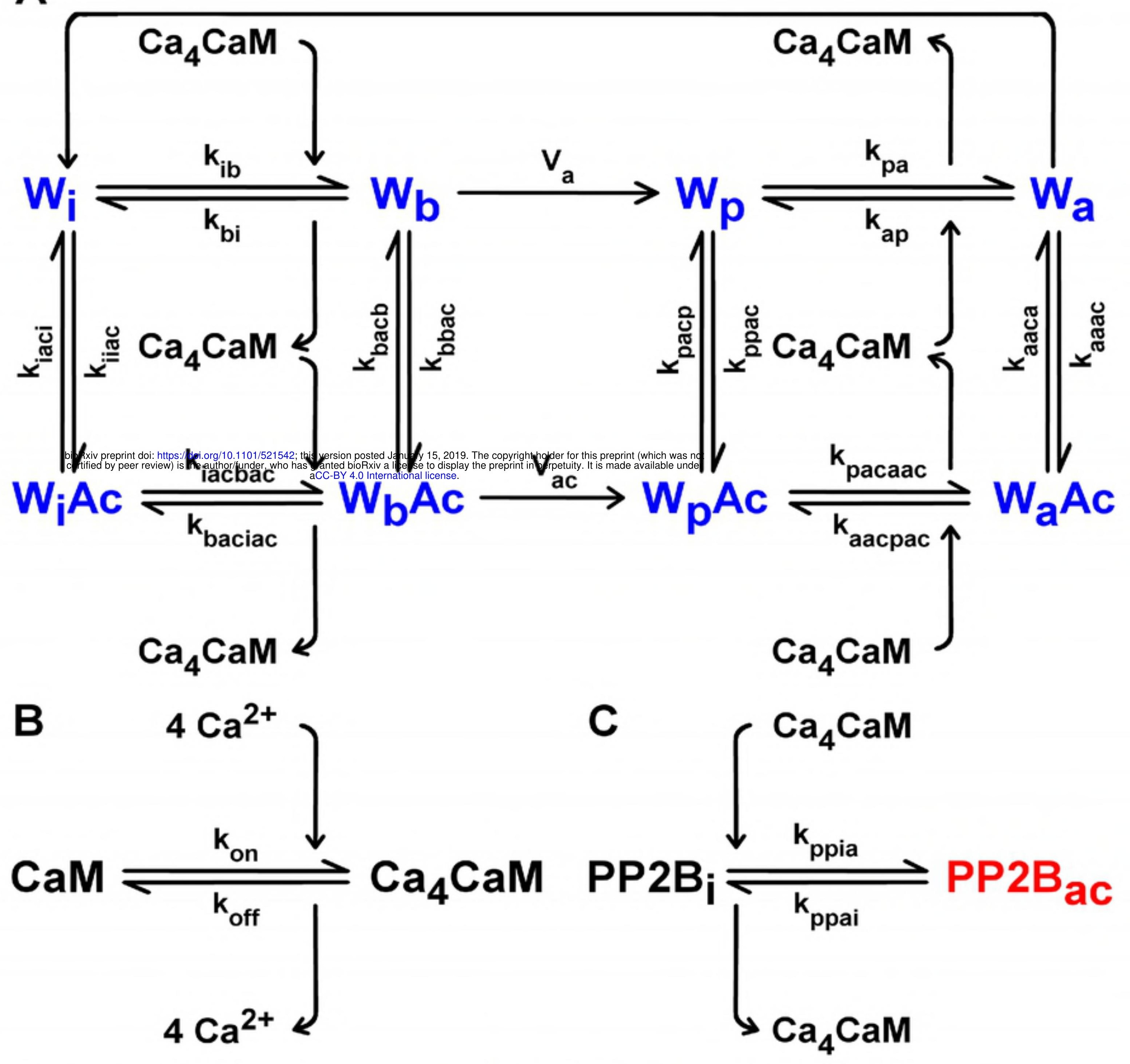

D



Figure 2 


\section{A}

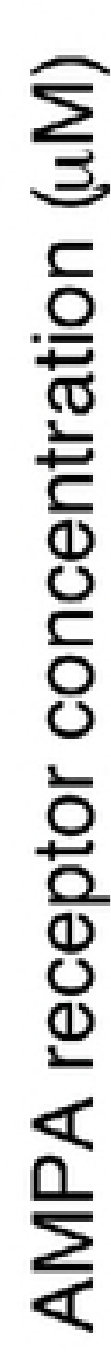

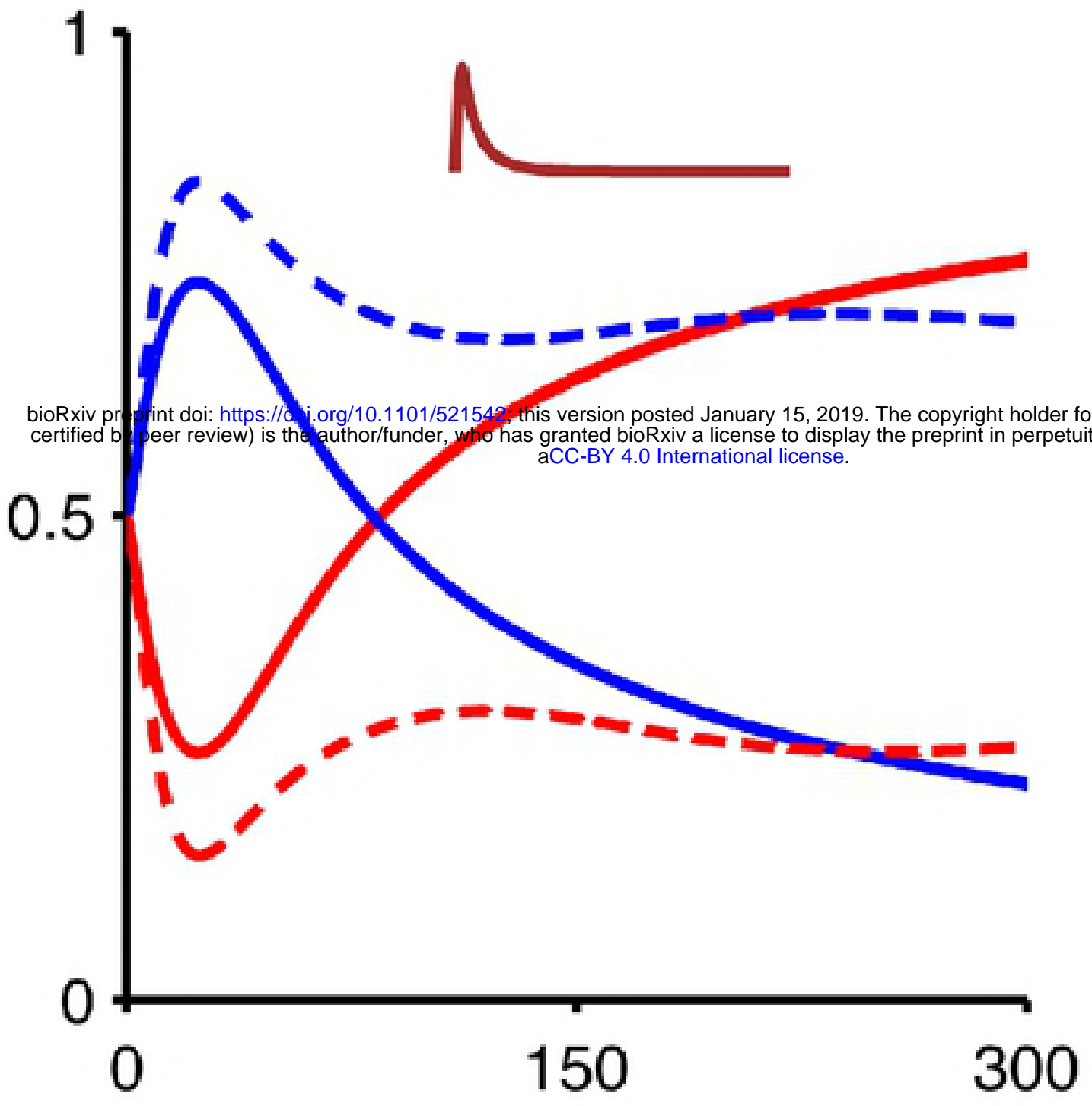

B

列

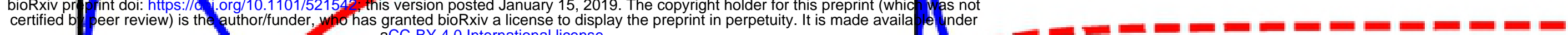

0.5

0.5

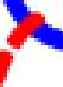


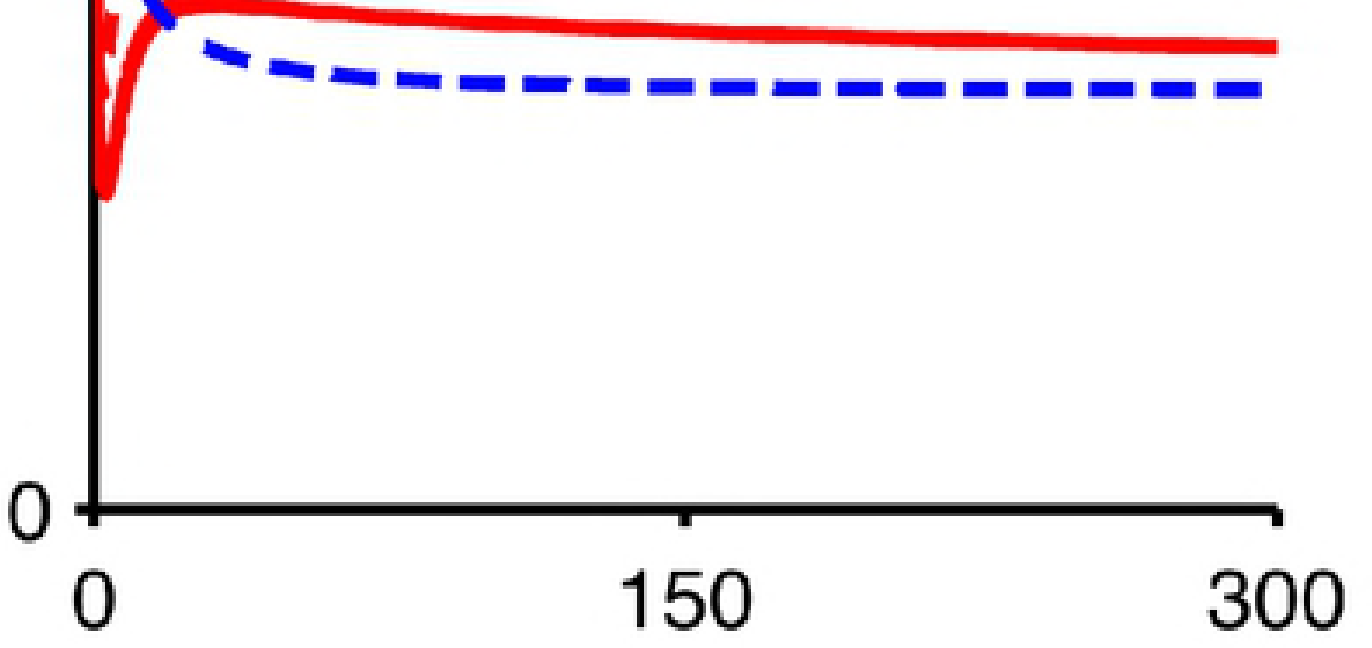

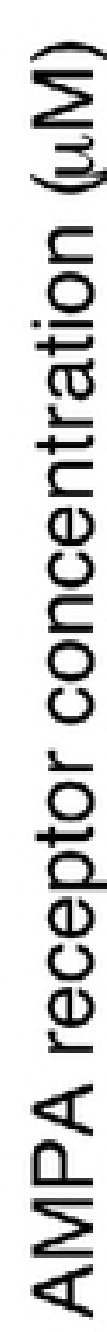


Figure 4 


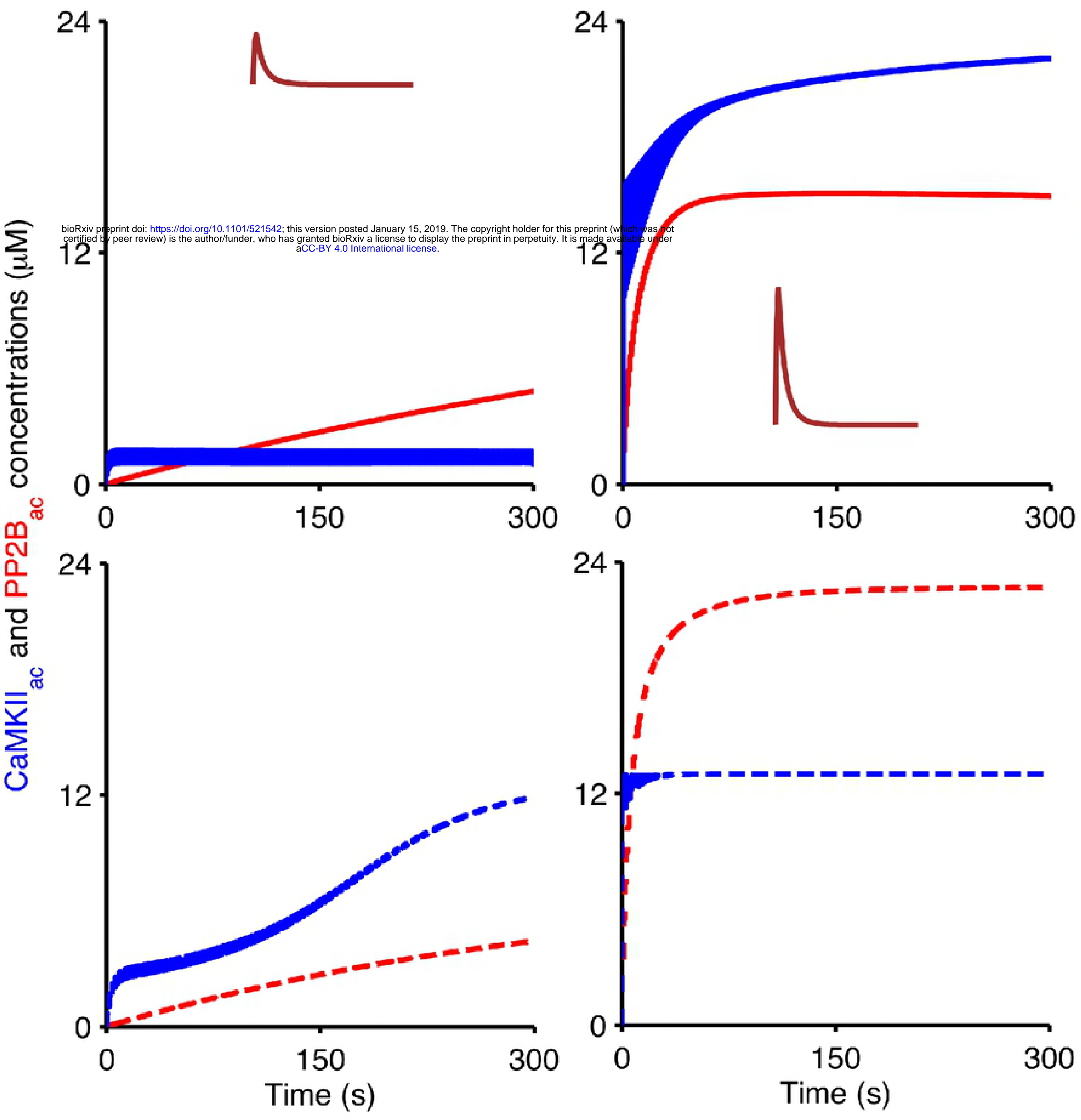

Figure 5 


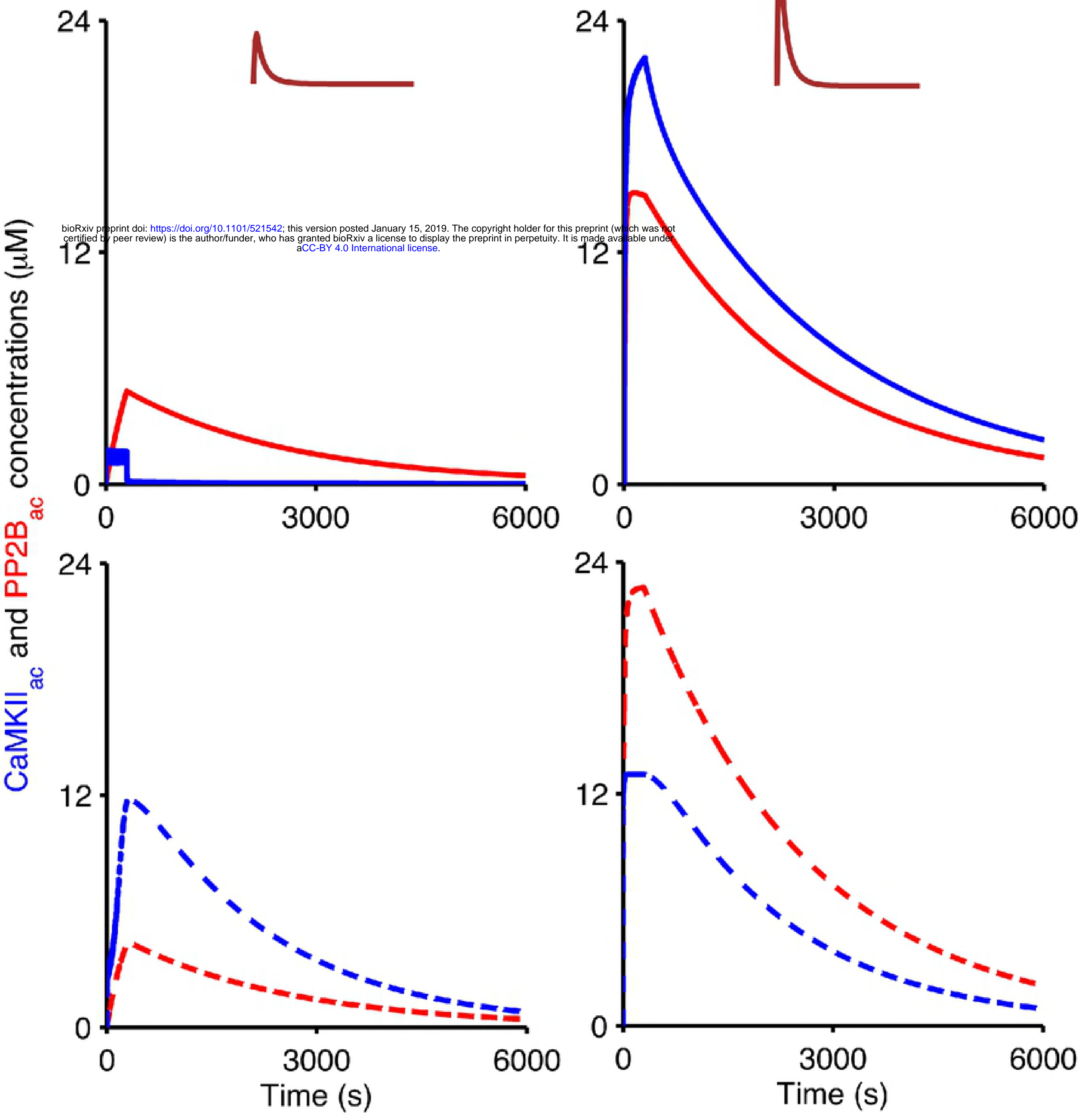

Figure 6 
